\title{
THE AUSTRALIAN HIGH COURT AND SOCIAL FACTS: A CONTENT ANALYSIS STUDY
}

\author{
Kylie Burns*
}

\begin{abstract}
Judicial reasons often include general statements about the nature and behaviour of people and institutions and the nature of the world and society. These statements might be called social facts ('SF') and are made as part of judicial development and general application of law. The presence of SF statements in judicial reasoning in Australian cases has been acknowledged by commentators and judges. However, there has been little empirical examination of this phenomenon. This article discusses a content analysis study of SF in negligence cases in the Australian High Court. This study confirms that judges do refer to SF in their judicial reasoning and that SF play a range of roles in judicial reasoning. This includes predicting social, economic and behavioural consequences of legal rules, as part of setting a context or background to judicial reasons, and as a tool to evaluate adjudicative facts. SF do not generally dominate judicial reasoning. However, they appear to have a significant role to play in certain complex and more important cases. While there were overall commonalities in the way judges used SF, some individual differences between judges emerged. Judges do not use SF in all cases in the same way. Judges referred to SF more in high significance cases, and cases with multiple separate judgments. Judges also referred to SF more in single and dissenting judgments than in joint and majority judgments. Most SF referred to by judges were not sourced or referenced in any way and reference to empirical research was very rare. Where a source or reference for a SF was given by a judge it was usually to a legal source. Most SF appeared to source from judicial 'common sense' with the potential dangers this brings to the accuracy and legitimacy of judicial reasoning.
\end{abstract}

\section{INTRODUCTION}

Judicial reasons often include general statements about the nature and behaviour of people and institutions ${ }^{1}$ and the nature of the world and society. These statements

* BA LLB (Hons) LLM PhD, Senior Lecturer, Griffith Law School. I thank Professor Richard Johnstone, Professor Jeff Giddings, Professor Jane Stapleton, Professor Peter Cane, Professor Sandra Berns, Professor Rosemary Hunter, Professor Ian Malkin, Professor Martin Davies and Professor A J Brown for their useful comments and advice on aspects of this study. I also thank the anonymous referees.

1 Including legal institutions and legal actors. 
might be called social facts ('SF'). SF are statements made as part of judicial development and general application of law ${ }^{2}$ SF are not 'adjudicative facts' relevant only to the parties to a particular dispute. ${ }^{3}$ Judicial reference to SF is not a recent phenomenon in the Australian High Court. For example, in 1933 in Australian Knitting Mills Ltd $v$ Grant, ${ }^{4}$ Starke J discussed Australian use of woollen undergarments and the nature of the risks of industrial processes. 'Woollen undergarments are commonly used, in Australia and elsewhere. ${ }^{15}$ 'But untoward results or accidents cannot, with the greatest of care, be wholly eliminated, in any industrial process. ${ }^{6}$ In 1939 in an early nervous shock case Chester $v$ The Council of the Municipality of Waverley, ${ }^{7}$ Latham CJ (in the majority who dismissed the claim), relying apparently on judicial common sense, considered it was not 'a common experience of mankind that the spectacle, even of the sudden and distressing death of a child, produces any consequence of more than a temporary nature'. ${ }^{8}$ Judges may also implicitly draw upon a range of unstated SF understandings as part of their reasoning. ${ }^{9}$ Explicit judicial SF statements are the 'tip of the iceberg' which represents overall judicial use of SF understandings.

2 The term 'social fact' as used in this article can be distinguished from the use of the term by others including Mullane, and Monahan and Walker. Mullane's use of the term refers only to a statement 'concerning human behaviour'. He argued the basis for 'social facts' may be 'revealed' by social scientific disciplines such as 'history, psychology, sociology, anthropology, political science and related fields.' See Graham R. Mullane, 'Evidence of Social Science Research: Law, Practice and Options in the Family Court of Australia' (1998) 72(6) Australian Law Journal 434, 434. Monahan and Walker's use of the term refers to the use of social scientific evidence relevant to issues in the case at hand, rather than in judicial law-making. See Laurens Walker and John Monahan, 'Social Facts: Scientific Methodology as Legal Precedent' (1988) 76 California Law Review 877.

3 Kenneth Culp Davis developed an influential distinction between 'adjudicative facts' and 'legislative' facts. Where a 'court or an agency finds facts concerning the immediate parties - who did what, where, when, how and with what motive or intent - the court or agency is performing an adjudicative function' so that the relevant facts are 'adjudicative facts'. Where a 'court or an agency develops law or policy, it is acting legislatively; the courts have created the common law through judicial legislation.' The use of facts in this context is referred to as 'legislative facts'. See Kenneth Culp Davis, 'Judicial Notice' (1955) 55(7) Columbia Law Review 945, 952. For Australian judicial discussion of the terms 'adjudicative fact' and 'legislative fact' see McHugh J in Woods $v$ Multi-Sport Holdings Pty Ltd (2002) 208 CLR 460, 478-9 [64]; and Heydon J in Aytugrul v R (2012) 286 ALR 441, 462-4 [70] -[74]. See also Hon J D Heydon, 'Developing the Common Law' in Justin Gleeson and Ruth Higgins (eds), Constituting Law: Legal Argument and Social Values (Federation Press, 2011) 93.

4 (1933) 50 CLR 387. The Privy Council appeal is reported at Grant v Australian Knitting Mills Ltd (1935) 54 CLR 49.

$5 \quad$ Australian Knitting Mills Ltd v Grant (1933) 50 CLR 387, 409.

6 Ibid 410

7 (1939) 62 CLR 1.

8 Ibid 10. This SF appears to be based on judicial use of 'common sense' assumptions about the psychological effects on parents of experiencing the death of a child. This kind of judicial assumption would not be supported today; see the High Court's decision in the Annetts case in Tame $v$ New South Wales (2002) 211 CLR 317.

9 Malbon refers to unarticulated 'judicial values' as the 'dark matter of judgments'. They form a critical part of the substance of the law, yet 'they can not be seen or clearly defined'. See 
SF find their way into judicial reasoning in a range of ways. SF may be the subject of expert evidence at trial, or may be admitted into evidence via evidential rules dealing with documentary and other special forms of evidence. ${ }^{10} \mathrm{SF}$ may be referred to in counsel's submissions or, rarely, in the High Court SF may source from the submissions of amicus curiae or interveners. ${ }^{11}$ Often SF appear to source from a judge's own knowledge or from a judge's own research (stated or unstated). It is unclear what the legal basis is for a judge to refer to SF (whether sourced from empirical research or otherwise) when that material has not been proved in evidence at trial. There is an unresolved question as to whether the doctrine of judicial notice or its statutory equivalent s 144 of the Evidence Acts ${ }^{12}$ apply only to adjudicative facts or can also apply to allow (or disallow) judicial use of SF not otherwise proved in evidence. ${ }^{13}$ Judicial use of more controversial SF may clearly fall outside the common law doctrine of judicial notice and s 144, particularly given many SF are not 'notorious' or universally and widely accepted. ${ }^{14}$ Justice Heydon has suggested some SF are, however, of the 'common knowledge' kind which form an inherent part of the judicial law making function and fall outside the rules of evidence. ${ }^{15}$

The recent High Court decision of Aytugrul v $R^{16}$ appears to interpret s 144 of the Evidence Acts to restrict judicial use of empirical research in support of SF used in the determination of legal principles unless the material has been admitted into evidence at trial, or the material otherwise fulfils the strict requirements of s 144 and notice has been given to the parties. ${ }^{17}$ The High Court held that published empirical research

Justin Malbon, 'Judicial Values' in Ian Freckleton and Hugh Selby (eds), Appealing to the Future: Michael Kirby and His Legacy (Law Book, 2009) 579, 581.

10 For example, SF material may be introduced pursuant to evidential rules regarding official documents and official records, or via particular sections of legislation such as the Family Law Act 1975 (Cth). See Mullane, above n 2, 448-52.

11 The role of interveners and amicus curiae in the High Court is relatively restricted, see George Williams, 'The Amicus Curiae and Intervener in the High Court of Australia: A Comparative Analysis' (2000) 28 Federal Law Review 365.

12 Evidence Act 1995 (Cth); Evidence Act 1995 (NSW); Evidence Act 2001 (Tas); Evidence Act 2008 (Vic). Section 144 of the Evidence Acts provides that 'proof is not required of knowledge that is not reasonably open to question', and is common knowledge in the relevant locality or generally, or is 'capable of verification by reference to a document' where the authority of the document cannot be reasonably questioned.

13 See discussion in Heydon, above n 3; Mullane, above n 2; Stephen Gageler, 'Fact and Law' (2008-9) 11 Newcastle Law Review 1, 18-29; Zoe Rathus, 'A Call for Clarity in the Use of Social Science Research in Family Law Decision-making' (2012) 26 Australian Journal of Family Law 81, 84-9; Bradley Selway, 'The Use of History and Other Facts in the Reasoning of the High Court of Australia' (2002) 20 University of Tasmania Law Review 129, 131.

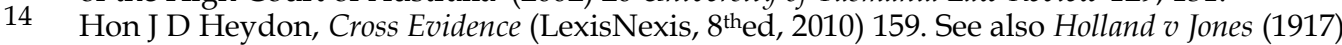
23 CLR 149, 153. For further recent discussion of the doctrine of judicial notice see Paul Burgess, 'The Application of the Doctrine of Judicial Notice to Online Sources' (2010) 3(1) Queensland Law Student Review 1.

15 Aytugrul v R (2012) 286 ALR 441, 463-4 [73]. See also Selway, above $\mathrm{n}$ 13. This matter was also debated by Callinan J and McHugh J in Woods $v$ Multi-Sport Holdings Pty Ltd (2002) 208 CLR 460 with McHugh J (at 477-8) arguing that SF empirical material was within the scope of judicial notice and could be used to define the scope and validity of law and Callinan J suggesting that the use of such material was impermissible (at 184-5).

16 (2012) 286 ALR 441.

17 See above $\mathrm{n} 12$. 
regarding jury perceptions of DNA evidence could not be used to support a new legal principle in relation to exclusion of prejudicial evidence. ${ }^{18}$ In that case the material was not introduced at trial via expert evidence, but rather was introduced in the dissenting judgment of McClellan CJ in the NSW Court of Appeal and was referred to in appellant's submissions to the High Court. ${ }^{19}$ The decision seems problematic in a number of respects. In particular it is still unclear whether there are any restrictions on judicial use of 'common sense' SF which are not based on any identified empirical or other research. This may have the invidious effect of excluding high quality published sources of SF information, while allowing judicial use of low quality intuitive or 'common sense' SF. An interpretation of the doctrine of judicial notice and s 144 which is overly restrictive in relation to empirical material may simply encourage judges to refer to such material to assist their reasoning but fail to cite the material in judgments. ${ }^{20}$ This difficult, unresolved issue regarding the legal basis for judicial use of SF is outside the scope of this article. Whatever the 'legal' position in relation to judicial use of SF, it is clear judges have not been completely (or perhaps even substantially) restrained in practice from referring to $S F$ in their judgments.

The presence of SF statements in judicial reasoning in Australian cases ${ }^{21}$ has been acknowledged and documented by a range of commentators including Burns, ${ }^{22}$ Mullane, ${ }^{23}$ Selway, ${ }^{24}$ Graycar, ${ }^{25}$ Serpell, ${ }^{26}$ Mason, ${ }^{27}$ Gageler ${ }^{28}$ and Malbon. ${ }^{29}$ It has been acknowledged by Australian High Court judges including Callinan J, ${ }^{30}$ McHugh $\mathrm{J},{ }^{31}$ Gleeson CJ, ${ }^{32}$ Heydon J, ${ }^{33}$ and Kirby J. ${ }^{34}$ There has also been judicial and academic

18 Aytugrul v R (2012) 286 ALR 441, 449 [21]-[22] (French CJ, Hayne, Crennan and Bell JJ).

19 See discussion in Rathus, above $\mathrm{n} 13,85-6$.

20 Ibid 89.

21 The term 'case' in this article refers to the reported or unreported overall judgment of a court in a particular matter.

22 Kylie Burns, 'The Way the World Is: Social Facts in High Court Negligence Cases' (2004) 12 Torts Law Journal 215; Kylie Burns, 'The High Court and Social Facts: A Negligence Case Study' in Michael Bryan (ed), Private Law in Theory and Practice (Routledge-Cavendish, 2007) 85; Kylie Burns, 'It's Just Not Cricket: The High Court, Sport and Legislative Facts' (2002) 10 Torts Law Journal 234.

23 See Mullane, above $\mathrm{n} 2$.

24 See Selway, above n 13.

25 Reg Graycar, 'The Gender of Judgments: An Introduction' in Margaret Thornton (ed), Public and Private: Feminist Legal Debates (Oxford University Press, 1995) 262; Reg Graycar 'Gender, Race, Bias and Perspective: OR, how Otherness Colours Your Judgment' (2008) 15(1-2) International Journal of the Legal Profession 73; Reg Graycar, 'The Gender of Judgments: Some Reflections on Bias' (1998) 32 University of British Columbia Law Review 1; Reg Graycar, 'Gendered Assumptions in Family Law Decision-Making' (1994) 22 Federal Law Review 278.

26 Andrew Serpell, The Reception and Use of Social Policy Information in the High Court of Australia (Law Book, 2006); Andrew Serpell, 'Social Policy Information: Recent Decisions of the High Court of Australia' (2011) 21 Journal of Judicial Administration 109.

27 Keith Mason, 'Ethics and the Environment' (2011) 10 The Judicial Review 187.

28 Gageler, above $\mathrm{n} 13$.

29 Malbon, above $\mathrm{n} 9$

30 Australian Broadcasting Corp v Lenah Game Meats Pty Ltd (2001) 208 CLR 199, 298 [252] (Callinan J).

31 Woods v Multi-Sport Holdings Pty Ltd (2002) 208 CLR 460, 479 [65] (McHugh J). 
discussion of SF in constitutional cases and as part of the interpretation of legislation. ${ }^{35}$ However, despite apparent judicial and scholarly acceptance that judges do sometimes refer to SF in their judicial reasoning, there has been little Australian empirical examination of this phenomenon. ${ }^{36}$ This potentially important aspect of how judges reason in the High Court (and other courts) has remained mysterious.

This article will discuss a content analysis study of SF in negligence cases in the Australian High Court. ${ }^{37}$ The study examined the role SF play in judicial reasoning, how frequently SF are referred to by judges, how SF are sourced by judges, and whether judicial reference to SF differs depending on the importance or significance of a case, the individual judges involved, and whether judgments are joint or single, in dissent or in the majority. Part 1 will outline the content analysis methodology used in the study. Part 2 discusses the role that SF play in judicial reasoning. Part 3 examines how frequently SF were used in the cases studied. Part 4 considers whether the frequency of SF differed depending on the importance or significance of a case. Part 5 focuses on the sources of SF. Part 6 discusses how frequently each of the individual High Court judges studied referred to SF and how those SF were sourced. Finally, Part 7 examines whether the frequency of SF in an individual judgment ${ }^{38}$ differed depending on whether a judge was in a single judgment or joint judgment, and by whether a judge's reasons formed part of a dissent or majority decision in a case.

Overall this study confirms that judges in the Australian High Court do refer to SF in their judicial reasoning, despite apparent uncertainty regarding the legal basis for

32 Chief Justice Murray Gleeson, 'The High Court of Australia: Challenges for its New Century' (Paper presented at the 2004 Constitutional Law Conference, Parliament House, Sydney, 20 February 2004) <http://www.hcourt.gov.au/assets/publications/speeches /former-justices/gleesoncj/cj_20feb04.html>.

33 Heydon, above n 3. See also Aytugrul v R (2012) 286 ALR 441, 462-3 [71] where Heydon J refers to a wide range of High Court cases in which the High Court has referred to SF material to aid in the development and application of legal principle where that material was not tendered in evidence at trial.

34 Hon Michael Kirby, 'Judicial Activism? A Riposte to the Counter-Reformation' (2004) 24 Australian Bar Review 219.

35 See the discussion of 'legislative facts' and 'constitutional facts' by Heydon J in Thomas $v$ Mowbray (2007) 233 CLR 307, 512-22 [613]-[640]. See also Susan Kenny, 'Constitutional Fact Ascertainment' (1990) 1 Public Law Review 134. This is also discussed in Gageler, above $\mathrm{n}$ 13.

36 Mullane has examined the use of social facts in the Family Court. See Mullane, above n 2. I have previously examined the use of social facts in negligence cases in the High Court, in a preliminary stage of this study. See Burns, 'The Way the World Is' and 'The High Court and Social Facts' above $n 22$.

37 The study was restricted to High Court cases and did not examine trial or lower appellate court judgments or parties' oral and written submissions except by way of background in selected instances. The study was conducted within an interpretivist (rather than positivist) epistemological paradigm and utilised a social constructionist approach. A qualitative, rather than a quantitative, approach was taken to the content analysis. The study did not undertake complex statistical analysis or modelling of the data as a quantitative content analysis might have done. Rather, the frequency and sourcing of SF identified in the study will be reported by number and percentage where relevant.

38 The term 'judgment' is used to refer to each individual judicial judgment (single or joint) within an overall court decision on a case. 
judicial use of SF. SF play a range of roles in judicial reasoning in the Australian High Court including to predict future social, economic and behavioural consequences of legal rules, ${ }^{39}$ as part of setting a context or background to judicial reasons, ${ }^{40}$ and as a tool to evaluate adjudicative facts. ${ }^{41} \mathrm{SF}$ do not generally dominate the text of judicial reasoning. However, they do appear to have a significant role to play in certain complex and more important cases. Judges did not use SF in all cases in the same way. Judges referred to SF more in high significance cases and cases with multiple separate judgments. Judges also referred to SF more in single and dissenting judgments than in joint and majority judgments. Most SF referred to by judges were not sourced or referenced in any way. Most SF appeared to source from judicial 'common sense' with the potential dangers this brings to the accuracy and legitimacy of judicial reasoning. Where a source or reference for a SF was given by a judge it was usually to another reported or unreported case or some other legal source. Judicial reference to empirical research was very rare. There were overall commonalities in the way different judges used SF. For example, all judges mostly gave no reference for their SF statements, or referred to cases or legal sources. However, some differences between individual judges emerged with some variations in the frequency with which judges used SF in their judgments, and in the manner in which they sourced or referenced SF.

\section{CONTENT ANALYSIS METHODOLOGY}

Despite the rapid growth of empirical research based on the judicial decisions and judgments of courts in the United States, ${ }^{42}$ very little Australian empirical research ${ }^{43}$ has focussed on the textual content of Australian High Court judgments. ${ }^{44}$ Serpell has

39 For example a judge might suggest that a particular legal rule would create undue burdens for business or commerce. Serpell refers to these judicial statements of consequence as 'social policy'. See Serpell, above n 26.

40 For example a judge might suggest that the social and economic position of women in Australian society has changed in recent times. See for example De Sales v Ingrilli (2002) 212 CLR 338, 392 [153] (Kirby J).

41 For example a judge may discuss how people generally act when intoxicated, to evaluate how a particular party to the litigation may have acted. See Cole $v$ South Tweed Heads Rugby League Football Club Ltd (2004) 217 CLR 469, 478 [17] (Gleeson CJ). Monahan and Walker refer to this as 'social framework'. See Laurens Walker and John Monahan, 'Social Frameworks: A New Use of Social Science in Law' (1987) 73 Virginia Law Review 559.

42 For example see discussion in Mark A Hall and Ronald F Wright, 'Systematic Content Analysis of Judicial Opinion' (2008) 96 California Law Review 63; Richard A. Posner, How Judges Think (Harvard University Press, 2008).

43 Obviously there is significant published work utilising standard legal analysis including analysis of High Court case law. Heise has argued that '[a]ssertions unconnected to an empirical basis fill law review articles (and judicial opinions)'. This occurs, he argues, because little expertise is required to gather anecdotal evidence and it is relatively 'simple and transparent'. See Michael Heise, 'The Importance of Being Empirical' (1999) 26 Pepperdine Law Review 807, 808.

44 There is an emerging body of other empirical work on the Australian High Court which studies citation patterns, dissent, and the impact of judicial ideology on case outcomes. Examples include Russell Smyth, 'Academic Writing and the Courts: A Quantitative Study of the Influence of Legal and Non-legal Periodicals in the High Court' (1998) 17 University of Tasmania Law Review 164; Russell Smyth, 'Other than "Accepted Sources of Law"?: A Quantitative Study of Secondary Source Citations in the High Court' (1999) 22 University of 
conducted legal case study research on the use of social policy ${ }^{45}$ by the High Court which analysed a small number of High Court cases to show that judges in the Australian High Court referred to social policy. ${ }^{46}$ Studies have also examined the use of the terms 'trite' and 'trite law' in High Court cases ${ }^{47}$ and utilised computational linguistics to investigate the authorship of High Court opinions. ${ }^{48}$ I conducted a pilot version of this study, focussing on SF in High Court negligence cases decided in $2003 .{ }^{49}$

This study used qualitative content analysis to investigate SF in 45 Australian High Court negligence cases from 2001-2005. Content analysis is an empirical method that involves the collection of a set of documents, reading the documents systematically, recording consistent features of the documents and drawing inferences from the data recorded. 50 Content analysis is used to analyse texts and images, and 'often involves thematic categorisation or coding, as well as counting the frequency with which those themes and codes appear. ${ }^{51}$ It has not been widely used by legal researchers, although

New South Wales Law Journal 19; Ian Ramsay and GP Stapledon, 'A Citation Analysis of Australian Law Journals' (1997) 21 Melbourne University Law Review 676; Matthew Groves and Russell Smyth, 'A Century of Judicial Style: Changing Patterns in Judgment Writing on the High Court 1903-2001' (2004) 32 Federal Law Review 255; Andrew Lynch, 'Dissent: Towards a Methodology for Measuring Judicial Disagreement in the High Court of Australia' (2002) 24 Sydney Law Review 470; Andrew Lynch, 'The Gleeson Court on Constitutional Law: An Empirical Analysis of its First Five Years' (2003) 26 University of New South Wales Law Journal 32; Andrew Lynch, 'Does the High Court Disagree More Often in Constitutional Cases? A Statistical Study of Judgment Delivery 1981-2003' (2005) 33 Federal Law Review 485; Russell Smyth, 'What Explains Variations in Dissent Rates?: Time Series Evidence from the High Court' (2004) 26 Sydney Law Review 221; Russell Smyth, 'The Role of Attitudinal, Institutional and Environmental Factors in Explaining Variations in the Dissent Rate on the High Court of Australia' (2005) 40 Australian Journal of Political Science 519; Russell Smyth, '"Some are More Equal Than Others"-An Empirical Investigation into the Voting Behaviour of the Mason Court' (1999) 6 Canberra Law Review 193; Russell Smyth, 'Explaining Voting Patterns on the Latham Court 1935-50' (2002) 26 Melbourne University Law Review 88; Jason Pierce, 'Institutional Cohesion in the High Court of Australia: Do American Theories Travel Well Down Under?' (2008) 46 Commonwealth and Comparative Politics 318; Jason L Pierce, Inside the Mason Court Revolution: The High Court of Australia Transformed (Carolina Academic Press, 2006).

45 For the definition of social policy, see above $\mathrm{n}$ 39. The term SF in this study was not confined to statements of social policy or consequence, but did include those statements.

46 See Serpell, above n 26. Serpell's original study discussed case studies of four High Court cases and his 2011 study discussed case studies of a further three cases.

47 Richard Haigh utilised the AUSTLII and Lexis Caselaw databases to investigate the use of the terms 'trite' and 'trite law' in the text of High Court decisions. See Richard Haigh, 'It is Trite and Ancient Law: The High Court and the Use of the Obvious' (2000) 28 Federal Law Review 87.

48 See Yanir Seroussi, Russell Smyth and Ingrid Zukerman, 'Ghosts from the High Court's Past: Evidence from Computational Linguistics for Dixon Ghosting for McTiernan and Rich' (2011) 34 University of New South Wales Law Journal 984.

49 Burns, above $\mathrm{n} 22$.

50 Hall and Wright, above n 42, 65. This differs from more traditional legal methods of analysis as it allows for analysis of whole bodies of case law to make generalisable findings, rather than analysis of selected cases only and reliance on 'anecdotal' findings.

51 Lisa Webley, 'Qualitative Approaches to Empirical Legal Research' in Peter Cane and Herbert Kritzer (eds), The Oxford Handbook of Empirical Legal Research (Oxford University 
Hall and Wright document its increasing use by American scholars studying the content of judicial opinions. ${ }^{52}$ There are Australian examples of the use of content analysis to study legal phenomenon and documents such as judgments and judicial decisions, print media and material produced by government agencies. ${ }^{53}$ However, apart from my pilot study of negligence cases in 2003, content analysis has not been previously used to study SF in cases in the High Court of Australia.

This content analysis study was based on 45 High Court negligence ${ }^{54}$ cases, where judgments were handed down by the High Court during the five calendar years of 2001-2005. The period of 2001-2005 allowed (as far as possible) a stability in the composition of the High Court during the period studied. ${ }^{55}$ All High Court negligence

Press, 2010) 927, 941. It can be 'descriptive' as well as being used to 'explain or develop' theories. Hall and Wright, above n 42, 65 citing Klaus Krippendorf, Content Analysis: An Introduction to Its Methodology (SAGE, $2^{\text {nd }}$ ed, 2004) 18, note that content analysis is utilised to provide 'replicable and valid inferences from texts'. This of course is the perspective of positivist 'classical' accounts of content analysis. More interpretative models of content analysis do not place as much emphasis on concepts such as validity and replicability.

52 Hall and Wright, above n 42, 65, writing about the emerging use of content analysis to study judicial opinions in the United States, note that legal scholars have developed 'their uses of content analysis organically'. Reference to methodological literature has been rare. They argue that content analysis is 'perfectly suited' for examination of judicial reasoning.

53 Australian 'legal' examples of the use of content analysis include Chris Dent and Andrew T Kenyon, 'Defamation Law's Chilling Effect: A Comparative Content Analysis of Australian and US Newspapers' (2004) 9(2) Media and Arts Law Review 89; Elena Marchetti, 'Indigenous Women and the RCIADIC: Part I.' (2007) 7(1) Indigenous Law Bulletin 6; Elena Marchetti, 'Indigenous Women and the RCIADIC: Part II' (2007) 7(2) Indigenous Law Bulletin 6; Jane Wangmann, 'Gender and Intimate Partner Violence: A Case Study from NSW' (2010) 33 University of New South Wales Law Journal 945; Lorana Bartels, 'To Suspend or Not to Suspend: A Qualitative Analysis of Sentencing Decisions in the Supreme Court of Tasmania' (2009) 28 University of Tasmania Law Review 23; Lyn Hinds, 'Three Strikes and You're Out in the West: A Study of Newspaper Coverage of Crime Control in Australia' (2005-2006) 17 Current Issues in Criminal Justice 239; Karen Yeung, 'Does the Australian Competition and Consumer Commission Engage in Trial by Media' (2005) (27) Law and Policy 549; Maloney Lawrie, 'Do Fathers 'Win' or do Mothers 'Lose'?: A Preliminary Analysis of Closely Contested Parenting Judgments in the Family Court of Australia' (2001) 15(3) International Journal of Law, Policy and the Family 363 (see also the references to previous studies of the Family Court at 366-7); Deirdre Howard-Wagner, 'Who are the Real 'Heroes' and 'Villains': The Print Media's Role in Constructing the 'Public Liability Crisis' as a 'Moral Panic Drama" (2006-2008) 10 Newcastle Law Review 69; Rebecca Deering and David Mellor, 'Sentencing of Male and Female Child Sex Offenders: Australian Study' (2009) 16 Psychiatry, Psychology and the Law 394.

54 Cases were categorised as 'negligence' cases if they were indexed under the relevant CLR index or AustLII case headnote headings as being about negligence or damages (where the relevant case was a negligence case) and dealt with an element of a negligence action. Cases were not categorised as about 'negligence' if they were indexed only under private international law and dealt with issues arising out of that area of law, were indexed under workers' compensation (where a common law issue did not also arise), only dealt with issues relating to statutory accident compensation schemes, only dealt with limitation of actions procedures or other purely procedural issues (eg, pleading rules or damages interest calculations), or only raised issues arising from the Trade Practices Act 1974 (Cth).

55 This period included two judicial retirements (Gaudron J and McHugh J) and two judicial appointments (Heydon J and Crennan J). However, Crennan J did not take part in any 
judgments during those years were studied. ${ }^{56}$ These cases are listed in Appendix 1. This study was based on High Court negligence cases, rather than other cases, for a number of reasons. There is a longstanding debate about the use of policy in negligence cases and an apparent longstanding use of SF in negligence cases. ${ }^{57}$ Despite this, there has been very little empirical study of SF in negligence cases. Negligence cases also make up a relatively significant proportion of the overall appeal judgments handed down by the High Court. In 2001-2005, negligence cases comprised $12.12 \%$ of the overall appeal judgments. ${ }^{58}$ The apparent judicial use of SF in negligence cases also may potentially correlate with the reference by judges of the High Court to secondary source materials in their judgments. In his 1999 study, Smyth studied the citation patterns of secondary source material in High Court judgments published in the CLR in 1960, 1970, 1980, 1990 and 1996. ${ }^{59} \mathrm{He}$ found that in 1996 tort cases (including negligence cases) accounted for $13 \%$ of all cases where secondary material was cited by judges. ${ }^{60}$ This was second only to constitutional cases, which accounted for $44 \%$ of citations in that year. ${ }^{61}$

The High Court cases studied were coded as high significance, medium significance or low significance to allow an analysis of whether the frequency of judicial SF varied based on case complexity and importance. Given the absence of a similar study of the High Court, significance criteria were developed to reflect the complexity and importance of each case both from the perspective of the High Court itself and from the perspective of the legal profession and legal academy. ${ }^{62}$ The 'significance' factors considered for each case in determining the significance coding of the case included

negligence judgments handed down in late 2005 following her appointment and is not included in the content analysis study. Given the retirement of Gaudron J early in the study period, the majority of judgments studied in the content analysis did not include any judgments by a female judge. The time period chosen was also one during which the state of negligence law was in a rapid period of transition. See Harold Luntz, 'Torts Turnaround Downunder' (2001) 1 Oxford University Commonwealth Law Journal 95.

56 Accordingly, no sampling issues arose. All cases were coded from the electronic full text version of the High Court judgments for 2001-2005 available on AustLII.

57 See, for example, discussion in Harold Luntz, 'The Use of Policy in Negligence Cases in the High Court of Australia' in Michael Bryan (ed), Private Law in Theory and Practice (Routledge-Cavendish, 2007) 55; Christian Witting, 'Tort Law, Policy and the High Court of Australia' (2007) 31 Melbourne University Law Review 569; Andrew Robertson, 'Constraints on Policy-Based Reasoning in Private Law' in Andrew Robertson and HW Tang (eds), The Goals of Private Law (Hart Publishing, 2009) .

58 Over the relevant period, the negligence cases in this study made up $12.12 \%$ of all appeal judgments handed down by the High Court (44/363 appeal judgments handed down in 2001-2005) and $15.06 \%$ of all civil appeal judgments (44/292 civil appeal judgments). The number of appeal judgments is drawn from the High Court of Australia Annual Reports available at High Court of Australia, Annual Reports <http://www.hcourt.gov.au/ publications/annual-reports/annual-reports>.

59 Smyth, 'Other than Accepted Sources of Law', above n 44

60 Ibid 33.

61 Ibid. Smyth notes that this accords with American studies which found that constitutional cases in the United States accounted for the highest rate of secondary citations. Smyth accounts for this on the basis of the difficult interpretation issues in constitutional cases and also the predominance of constitutional cases in the caseload of the court.

62 Searches of the database CASEBASE were utilised to gather this information for each case studied. 
whether the case was about a novel, difficult or unresolved legal issue directly related to one of the elements of negligence, whether it was reported in the authorised reports (CLR), how many High Court judges sat on the case, how frequently in the five years following the case it had been cited and applied in other negligence cases, and how frequently in the five years following the case it had been discussed in journal articles. ${ }^{63}$ The more criteria the case satisfied, the more likely it was to be coded as high significance. For example, a case that was only reported in the ALR, only tangentially related to an element of negligence, involved only three judges, and had not been cited frequently in cases or articles was coded as low significance. ${ }^{64}$ Cases which were about a critical aspect of an element of negligence, involved the full court, were lengthy involving multiple judgments, were reported in the CLR, and were cited frequently in cases or articles were coded as high significance. ${ }^{65}$

Each case was coded for the number of overall judgments in a case. Each SF in every judgment was recorded and entered into an ACCESS database. Each recorded SF as far as possible dealt with a single subject matter. ${ }^{66} \mathrm{SF}$ in a judgment which were derived from quotes or reasoning from a lower court judgment or other case, expert witness testimony or counsel's submissions, were only entered into the database as a SF where the relevant High Court judge explicitly adopted or accepted the statement in support of judicial reasoning as part of their determination of the case. SF which occurred when a judge was simply restating a summary of the facts or lower court findings or the parties' arguments or submissions were not included. Each individual $\mathrm{SF}^{67}$ in a judgment was coded for the judge or judges who made it, whether it was referenced 68 and if so what kind of reference, whether it was in a single or joint judgment, and whether it was in a dissent ${ }^{69}$ or majority judgment. ${ }^{70}$

63 This form of qualitative coding has an inherent subjective element, as do other forms of interpretative qualitative (and even quantitative) empirical research. For this reason, the significance coding of cases is indicated in Appendix 1 so that coding choices are clearly apparent to other researchers.

64 For example Manley $v$ Alexander (2005) 223 ALR 228

65 For example Cattanach v Melchior (2003) 215 CLR 1.

66 Where more than one SF about the same subject matter occurred in a single numbered paragraph of a judgment, they were coded as a single SF record. However, where a SF about the same subject matter occurred in a subsequent numbered paragraph, it was coded as a new SF record.

67 The general definition of SF discussed in the introduction to this article was used to identify SF. More detailed coding instructions in relation to the application of the definition of SF are held on file with the author.

68 A SF was recorded as referenced when a footnote reference was provided for at least part of the statement (even if not for all of the statement) or when it was made clear in the text of the SF that it was sourced to some other source such as an expert witness, counsel's brief or an intervener. If a judge only explicitly cited their own previous judgment in a case, that was not counted as a reference.

69 There is a methodological debate about how to categorise High Court judgments, as either majority or dissenting judgments, for the purpose of dissent studies. See, eg, Lynch, 'Dissent: Towards a Methodology for Measuring Judicial Disagreement in the High Court of Australia', above $\mathrm{n} 44$. This study adopted the simple method of categorising a judgment as a majority judgment if it concurred with the majority on the overall resolution of the appeal, either allowing or dismissing the appeal on the orders. A judgment was coded as a majority judgment if it concurred with the majority on the overall resolution of the appeal, 


\section{THE ROLE OF SOCIAL FACTS IN JUDICIAL REASONING}

The results of the content analysis of negligence cases from 2001-2005 clearly showed that High Court judges did use SF as part of judicial reasoning. Examples ${ }^{71}$ included:

The rejection of this appeal will reinforce indifference and belated and formal offers of transport by a club where proper standards of reasonable care require a significantly more prompt and higher standard of attention to the case of such a vulnerable individual. ${ }^{72}$

Risk of action does no doubt conduce to the defensive practice of a profession, in turn leading to delay and unnecessary expense. ${ }^{73}$

... the majority reasoning tends to generate litigation about children capable of causing the children distress and injury if they hear about it. 74

Much of the scholarship regarding tort law and negligence law focuses on the permissibility (and impermissibility) of the use of 'policy' or consequence based arguments in negligence cases. ${ }^{75}$ However, the study confirmed that SF played a much broader role in judicial reasoning. While there were examples of High Court judges referring to policy or consequence concerns (see the three SF examples above) judges did not only use SF as part of 'policy' or consequence based reasoning.

Judges used SF in their judicial reasons in a range of other ways including to measure or evaluate adjudicative facts ('social framework') ${ }^{76}$ and as part of the creation of general background or context to a decision. 'Social framework' SF were used to identify whether particular elements of negligence were satisfied on the facts of the case (for example the nature or severity of a particular risk, whether a particular risk was foreseeable, whether appropriate precautions were taken by a defendant or whether a breach of duty had occurred). Examples of 'social framework' SF identified in the study included:

They have a loving relationship with a healthy child. It does not involve any special financial or other responsibilities that might exist if, for example, the child had an unusual and financially burdensome need for care. The financial obligations which the respondents have incurred, legal and moral, are of the same order as those involved in any ordinary parent-child relationship. ${ }^{77}$

In a social, as in a commercial, context, the risk of injury associated with the consumption of alcohol is not limited to cases where there is an advanced state of intoxication.

even if some aspects of the judicial reasoning differed among the majority judges or where there was dissent on a costs or procedural issue only. See Smyth, 'The Role of Attitudinal, Institutional and Environmental Factors in Explaining Variations in the Dissent Rate on the High Court of Australia', above $\mathrm{n} 44$.

70 More detailed coding instructions and the ACCESS database recording the data are on file with the author.

71 The SF in the examples quoted are in italics.

72 Cole v South Tweed Heads Rugby League Football Club (2004) 217 CLR 469, 499 [106] (Kirby J).

73 D'Orta-Ekenaike v Victoria Legal Aid (2005) 223 CLR 1, 117 [374] (Callinan J).

74 Cattanach $v$ Melchior (2003) 215 CLR 1, 126 [347] (Heydon J).

75 See above $n$ 57. On the use of 'social policy' based arguments in other categories of case in the High Court of Australia see Serpell, above n 26.

76 See Walker and Monahan, above $\mathrm{n} 41$.

77 Cattanach $v$ Melchior (2003) 215 CLR 1, 22-3 [36] (Gleeson CJ). 
Depending upon the circumstances, a guest who has had a few drinks and intends to drive home may be at greater risk than a guest who is highly intoxicated but intends to walk home. ${ }^{78}$

The notion that the appellant, as far gone and as offensively abusive as she was, would have been amenable to counselling, or simple restraint, or indeed to any measures intended to restore her composure, is fanciful. Forceful restraint was out of the question. No sensible person would ever remotely contemplate such a course, capable, as it would be, of leading to a physical altercation, an assault, and the possibility of criminal and civil proceedings in relation to it. ${ }^{79}$

The study also identified SF that were used more generally (rather then specifically) to frame judicial assessment of the circumstances pertaining to a case, were used by judges to provide a context or general background to judicial reasons, or formed part of general judicial rhetorical reasoning. For example, in NSW v Bujdoso the unanimous High Court commented that '[m]any of the people in prisons are there precisely because they present a danger, often a physical danger to the community', and noted the propensity of prisoners to do 'grave physical injury to other prisoners'. ${ }^{80}$ It was acknowledged as 'notorious' that those convicted of sexual offences against minors are at greater risk of harm. ${ }^{81}$ In Cole $v$ South Tweed Heads Rugby League Football Club judges discussed the management practices of publicans and the nature of publican and customer relationships. ${ }^{82}$ In a range of cases judges discussed the work practices of police, how police act in investigations, how police resources are deployed, and the nature of police intelligence gathering. ${ }^{83}$ In several cases judges discussed the nature of commercial building and commercial development of premises and land. ${ }^{84}$ Judges in Neindorf $v$ Junkovic discussed the nature of residences of 'ordinary people', how they maintain those premises, the frequency of defects in ordinary people's houses, and the nature of hazards in ordinary houses. ${ }^{85}$ In the same case, garage sales were described as a 'familiar event in Australian suburbia'. ${ }^{86}$ In NSW $v$ Lepore members of the court

78 Cole v South Tweed Heads Rugby League Football Club (2004) 217 CLR 469, 478 [17] (Gleeson $\mathrm{CJ})$.

79 Ibid 504 [125] (Callinan J).

80 (2005) 227 CLR 1, 13-14 [44] (Gleeson CJ, Gummow, Kirby, Hayne, Callinan and Heydon $\mathrm{JJ})$.

81 Ibid.

82 Cole v South Tweed Heads Rugby League Football Club (2004) 217 CLR 469, 482 [35] (McHugh J), 506 [130] (Callinan J).

83 For example, Cole v South Tweed Heads Rugby League Football Club (2004) 217 CLR 469, 500 [108] (Kirby J), 504 [125] (Callinan J); D'Orta-Ekenaike v Victoria Legal Aid (2005) 223 CLR 1, 37 [102] (McHugh J); Sullivan v Moody (2001) 207 CLR 562, 581 [57] (Gleeson CJ, Gaudron, McHugh, Hayne and Callinan JJ); Tame v New South Wales (2002) 211 CLR 317, 430 [335] (Callinan J), 335 [26] (Gleeson CJ).

84 For example, Woolcock Street Investments Pty Ltd v CDG Pty Ltd (2004) 216 CLR 515, 528 [17] (Gleeson CJ, Gummow, Hayne and Heydon JJ), 549-50 [81]-[87] (McHugh J), 552-3 [95][96] (McHugh J), 554 [100] (McHugh J), 555 [103] (McHugh J), 557-8 [107]-[108] (McHugh J), 558-60 [110]-[114] (McHugh J), 562 [126] (Kirby J), 563 [129] (Kirby J), 579 [181] (Kirby J), 589 [213]-[214] (Callinan J), 590-1 [218] (Callinan J), 592 [223] (Callinan J); Tepko Pty Ltd v Water Board (2001) 206 CLR 1, 44 [133] (Kirby and Callinan JJ).

85 Neindorfv Junkovic (2005) 222 ALR 631, 633-4 [7]-[9] (Gleeson CJ), 634 [12] (Gleeson CJ), 635 [14] (Gleeson CJ), 637 [23] (Kirby J), 646-7 [59] (Kirby J), 648 [66] (Kirby J), 649 [69] (Kirby J), 650 [73] (Kirby J), 651 [75] (Kirby J), 654 [86] (Kirby J), 656 [94] (Kirby J), 656 [96] (Kirby J), 657 [100]-[101] (Callinan and Heydon JJ), 661 [116] (Callinan and Heydon JJ).

86 Ibid 657 [100] (Callinan and Heydon JJ). 
commented on the nature of school children, the nature of teaching, practices school authorities could adopt to prevent child sexual assault, and the prevalence of sexual assault. ${ }^{87}$ In a case that concerned physical injuries which occurred in a school playground, judges commented on a range of factors, including the nature of school students and the nature and costs of playground supervision. ${ }^{88}$

These findings confirmed that SF are not just used by judges of the High Court as part of traditional 'policy' or consequence based reasoning. SF play a much broader range of roles in High Court cases. They may be used by a judge to evaluate an adjudicative fact. They might also be used as part of building a general factual background to a matter, or as part of judicial rhetoric.

\section{HOW OFTEN DID JUDGES USE SF?}

As seen in Table 1 below, 1208 separate SF records were identified in the 45 High Court decisions (which included 158 separate judgments and 6676 separate paragraphs of text) studied. There was an average of 26.84 SF for every case studied, 7.65 SF for every judgment studied and one SF for every 5.52 paragraphs of text.

\section{Table 1 Number and Frequency of SF in Negligence Cases} 2001-2005

$\begin{array}{ll}\text { Number of Cases } & 45 \\ \text { Total Number of SF records } & 1208 \\ \begin{array}{l}\text { Total Number of Judgments (Individual and } \\ \text { Joint, Dissenting and Majority) }\end{array} & 158 \\ \text { Total Number of Judgment Paragraphs } & 6676 \\ \text { SF/Case } & 26.84 \\ \text { SF/Judicial Judgment } & 7.65 \\ \text { SF/Paragraph } & 1 \mathrm{SF} \text { per 5.52 paragraphs }\end{array}$

The tendency of judges to use SF in their judicial reasoning in the negligence cases studied did not appear to outweigh their tendency to refer to traditional sources of legal reasoning such as legal principles and adjudicative facts. As Table 1 shows, the majority of text in negligence decisions studied was made up of statements that were not SF - statements that were legal principles, adjudicative facts and statements which were in the nature of 'legal' values. ${ }^{89}$ This may give comfort to those who favour a more positivist or formalist version of judicial decision-making which rests on

87 New South Wales v Lepore (2003) 212 CLR 511,540 [53] (Gleeson CJ), 544 [66]-[67] (Gleeson CJ), 546 [74] (Gleeson CJ), 559 [123] (Gaudron J), 572-3 [164]-[165] (McHugh J), 583 [204] (Gummow and Hayne JJ), 586-7 [215]-[216] (Gummow and Hayne JJ), 587 [217]-[218] (Gummow and Hayne JJ), 581 [221] (Gummow and Hayne JJ), 594 [240]-[241] (Gummow and Hayne JJ), 602 [268] (Gummow and Hayne JJ), 604 [276] (Kirby J), 627 [327] (Kirby J), 625 [342] (Callinan J). For further discussion of the nature of investigation of child sexual abuse see Sullivan v Moody (2001) 207 CLR 562, 582 [62] (Gleeson CJ, Gaudron, McHugh, Hayne and Callinan JJ).

88 Trustees of the Roman Catholic Church for the Diocese of Canberra and Goulburn v Hadba (2005) 221 CLR 161, 170 [25] (Gleeson CJ, Hayne, Callinan and Heydon JJ), 171 [27] (Gleeson CJ, Hayne, Callinan and Heydon JJ), 174 [39] (McHugh J), 175 [44] (McHugh J), 176 [46] (McHugh J).

89 For example, matters of coherence and consistency. 
application of legal principles and legal values to adjudicative facts. However, of course, frequency counts of SF do not tell the whole story. It may be that even though a case contains a small number of SF, those SF may be highly influential in the ultimate determination of a case. ${ }^{90}$ In addition, judicial use of SF in the cases studied was not uniform. There were clusters of cases where SF were far more frequently used by judges, and clusters of cases where SF were used very little. This adds an extra level of complexity to how we understand judicial use of SF, and the role of SF in judicial reasoning. In some categories of cases it appears that even if frequency counts of SF are considered in the abstract, SF have a quite important role to play in judicial reasoning. In other categories of cases SF may have little or no role to play.

\section{DID THE SIGNIFICANCE OF CASES AFFECT THE FREQUENCY OF SF?}

In some cases SF played a more important role in judicial reasoning. A number of interrelated factors appeared to affect how frequently SF were used in a particular case. These factors included the significance of the case and the number of judgments in a case. Judges tended to use SF more in 'high significance' cases ${ }^{91}$ and cases with higher numbers of judgments. Appendix 2 shows the cases organised in order from the highest number of SF (Cattanach $v$ Melchior with $167 \mathrm{SF}$ ) to the lowest number of SF (Czatyrko $v$ Edith Cowan University and Manley $v$ Alexander with zero SF).

Cases which concerned complex, novel or highly disputed legal issues (which were coded as high significance cases) were more likely to include larger numbers of judicial SF statements. These included high profile cases during 2001-2005 such as Cattanach $v$ Melchior $^{92}$ (wrongful birth) with 167 SF, D'Orta-Ekenaike $v$ Victoria Legal Aid ${ }^{93}$ (advocates' immunity) with $138 \mathrm{SF}$, Tame $v$ New South Wales ${ }^{94}$ (duty of care for psychological injury) with $73 \mathrm{SF}$, Brodie v Singleton Shire Council ${ }^{95}$ (road authority immunity) with $61 \mathrm{SF}$, New South Wales $v$ Lepore ${ }^{96}$ (non-delegable duty/vicarious liability) with $45 \mathrm{SF}$ and Cole $v$ South Tweed Heads Rugby League Club ${ }^{97}$ (alcohol server's liability) with $43 \mathrm{SF}$. Cases which primarily concerned lower significance issues such as procedural, evidential, or damage calculation issues tended to have much lower numbers of SF. These included cases such as Czatyrko $v$ Edith Cowan University ${ }^{98}$ (contributory negligence on application of adjudicative facts) with zero SF, Shorey v PT

90 Future research utilising different methods would be required to determine this. This may also be an area of strength for more traditional doctrinal legal research.

91 As discussed above, cases were coded as high significance, medium significance or low significance. There were 16 high significance cases, 21 medium significance cases and eight low significance cases. The total number of judicial SF for each case was extracted from the overall SF database.

92 Cattanach v Melchior (2003) 215 CLR 1.

93 D'Orta-Ekenaike v Victoria Legal Aid (2005) 223 CLR 1.

94 Tame v New South Wales (2002) 211 CLR 317.

95 Brodie v Singleton Shire Council (2001) 206 CLR 512

96 New South Wales v Lepore (2003) 212 CLR 511.

97 Cole v South Tweed Heads Rugby League Football Club (2004) 217 CLR 469.

98 Czatyrko v Edith Cowan University (2005) 214 ALR 349. Manley v Alexander (2005) 223 ALR 228 (which concerned the interpretation of the relevant adjudicative facts in relation to whether a breach had occurred) also had zero SF. 
$L t d^{99}$ (determination of whether expert witness withdrew opinion and effect of this) with one SF, Willett $v$ Futcher ${ }^{100}$ (assessment of damages, investment advice fees) with one SF and Amaca Pty Ltd $v$ State of New South Wales ${ }^{101}$ (contribution, powers of court of appeal) with one SF.

As Graph 2 demonstrates, high significance cases were clearly the 'type' of case where judges were likely to refer to SF as a significant part of their judicial reasoning. ${ }^{102}$ Large differences can be seen between the average use of SF by judges in high significance cases and average judicial use of SF in low and medium significance cases. High significance cases had on average $56.25 \mathrm{SF} /$ case, with medium significance cases having only $12.9 \mathrm{SF} /$ case and low significance cases $4.63 /$ case.

\section{Graph 2: Average Number of SF/Case in each Category of Case Significance}

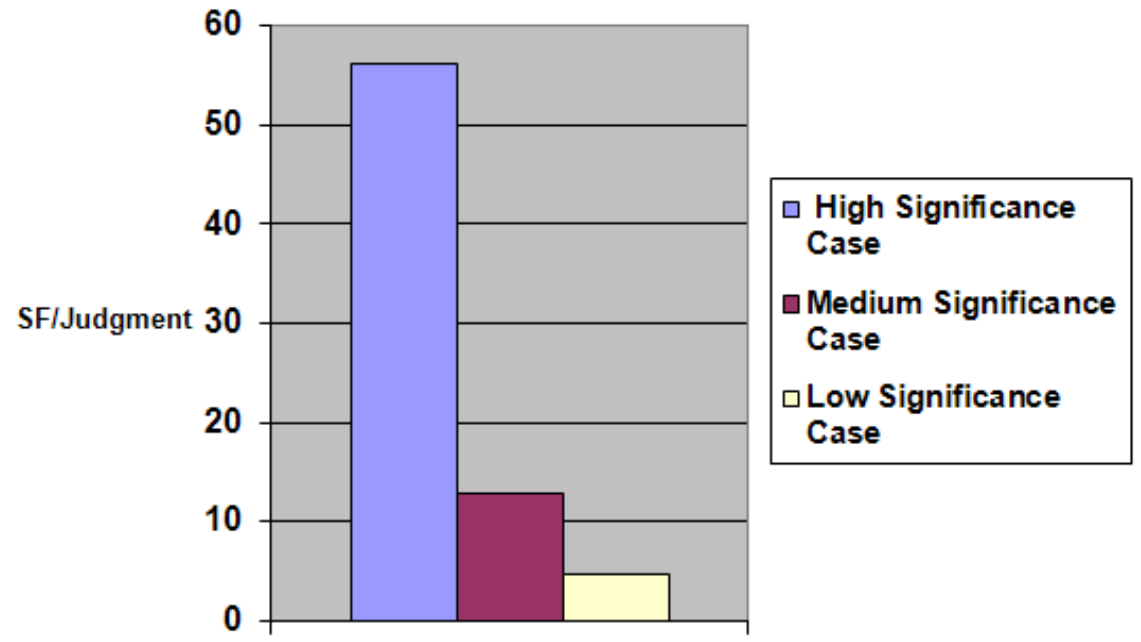

Signficance of Case

99 Shorey $v$ PT Ltd (2003) 197 ALR 410

100 Willett $v$ Futcher (2005) 221 CLR 627.

101 Amaca Pty Ltd $v$ New South Wales (2003) 199 ALR 596.

102 There were a small number of 'outlier' cases in the data, including Sullivan $v$ Moody (2001) 207 CLR 562 with only 4 SF. A number of factors may explain the low number of SF in this case despite its high significance. The case was a single unanimous judgment of only 66 paragraphs, highly unusual in High Court cases concerning novel or difficult legal issues. The High Court was particularly concerned in Sullivan $v$ Moody to limit the role of extralegal concerns and policy in the test for determination of duty of care in Australia. As discussed below, there was less judicial use of SF in cases where there were lower numbers of individual judgments. In addition, as discussed below joint majority judgments exhibited the lowest average number of SF/judgment. Finally, Kirby J did not sit as part of the High Court in Sullivan $v$ Moody. Kirby J was the highest judicial user of SF identified in the study. 
In addition, when the overall group of SF identified in the study were considered, a large majority of all SF came from high significance cases. Nine hundred SF $(74.5 \%$ of all SF) came from high significance cases, with 271 (22.4\%) from medium significance cases and only $37(3.1 \%)$ from low significance cases.

The number of judgments in a case was also related to the overall number of SF identified in a case. Cases with a larger number of judgments tended to have a larger number of SF. The number of judgments was also typically related to the overall significance or complexity of a case. ${ }^{103}$ The study found that the larger the number of judgments in a case, the larger the number of average SF in the case. As Graph 3 shows, six judgment cases had an average of $59.8 \mathrm{SF} /$ case, five judgment cases an average of $43.22 \mathrm{SF} /$ case, four judgment cases an average of $36.5 \mathrm{SF} /$ case, three judgment cases an average of $13.88 \mathrm{SF} /$ case, two judgment cases an average of 4.8 $\mathrm{SF} /$ case and one judgment cases an average of $2.38 \mathrm{SF} /$ case.

\section{Graph 3: Average Number of SF/Case and Number of Judgments in the Case}

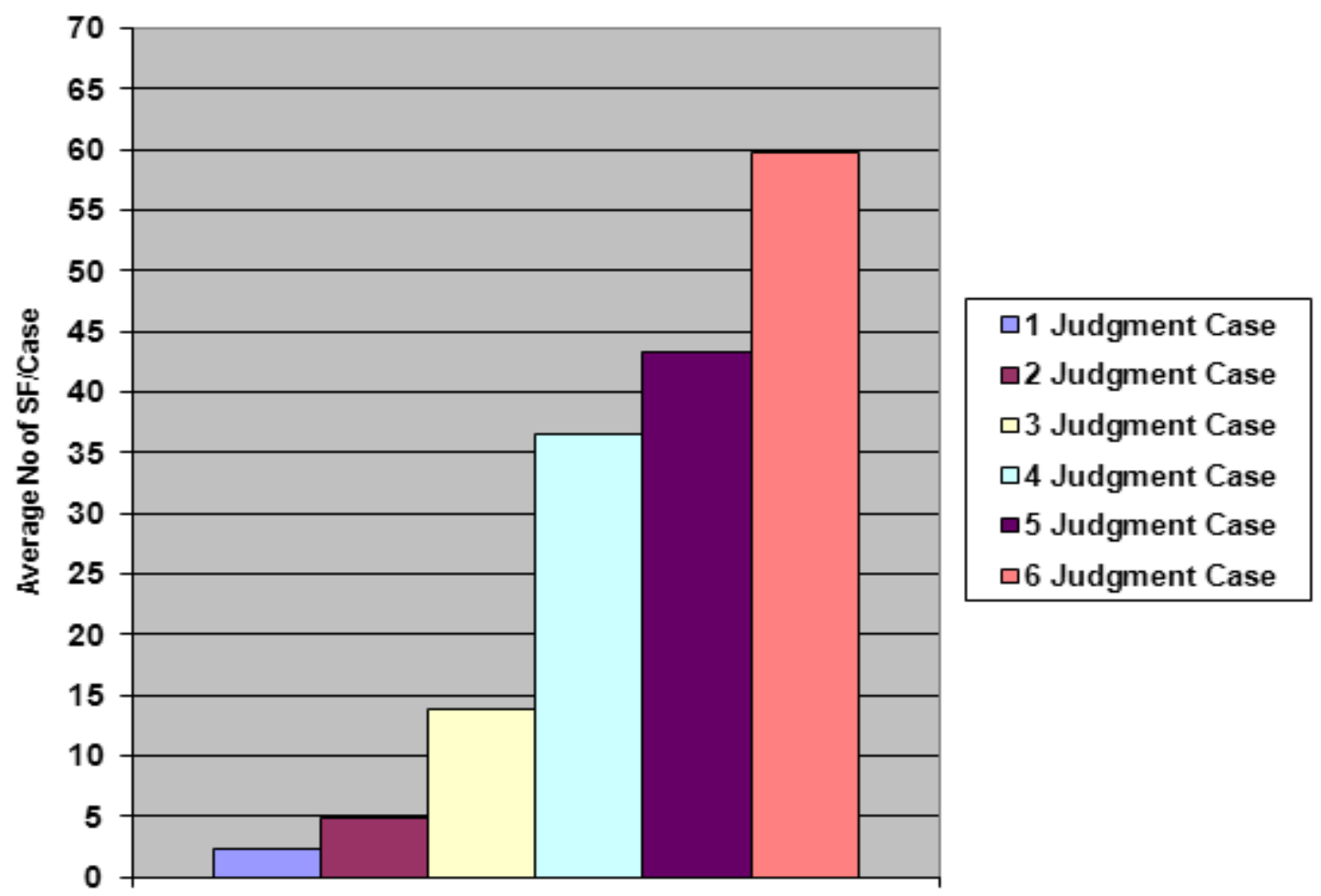

No of Judgments in Case

It is not surprising that cases with a larger number of judgments might have larger total numbers of SF-the more judgments there are in a case, the more opportunity

103 See Appendix 2. 
there is for judges to refer to SF. However, this study also found that higher numbers of judgments in a case was related to higher average numbers of SF/judgment. The more judges sat on a case, the more each judge in that case tended to use SF in their judicial reasons. Six judgment cases had an average of $9.9 \mathrm{SF} /$ judgment, five judgment cases had an average of $8.64 \mathrm{SF} /$ judgment, four judgment cases had an average of 9.13 $\mathrm{SF} /$ judgment, three judgment cases had an average of $4.63 \mathrm{SF} /$ judgment, two judgment cases had an average of $2.4 \mathrm{SF} /$ judgment and one judgment cases had an average of $2.38 \mathrm{SF} /$ judgment.

\section{SOURCES OF SF}

One of the key aspects of the Australian adversarial litigation system is the principle that judicial reasoning should be based on admissible (relevant and reliable) evidence and legal precedent. These principles lie at the very heart of Australian evidence law and practice. ${ }^{104}$ Judges are not 'participants' in the litigation, and generally are not 'permitted to go outside the evidence present and to act upon information privately obtained'. ${ }^{105}$ It might initially be expected, given the uncertainties in relation to the doctrine of judicial notice and its legislative equivalents discussed in the introduction to this article, that where judges use SF in their judgments those SF would be sourced from admissible evidence. Where SF are 'empirical' in nature (that is, they concern social, behavioural or scientific phenomena which have been empirically studied or are capable of empirical study) it might be expected that judges would refer to reliable empirical sources introduced in evidence or proved via expert witnesses. However, as this section shows, the content analysis conducted in this study found that judges most commonly did not refer to a source for SF in their judgments. Where judges referred to a source for a SF, it was typically to a 'legal' source such as another case. Judicial reference to empirical material was very rare. Table 4 shows that only $26 \%$ of all SF used by judges were referenced or sourced. This means that $74 \%$ of all SF used by judges were not sourced or referenced in any way.

\section{Table 4 Sources of SF}

Total Number of SF

Total Number of SF with judicial reference or source

Percentage of SF with judicial reference or source

Percentage of SF with no judicial reference or source

It is possible (and perhaps sometimes likely) ${ }^{106}$ that some of the SF used by High Court judges in the cases studied had an unstated source such as counsel's

104 Heydon, above n 14, 155.

105 Ibid.

106 Some cases did refer explicitly in some sections to SF evidence which had been given by expert witnesses. For example, see Swain v Waverley Municipal Council (2005) 220 CLR 517; Graham Barclay Oysters Pty Ltd $v$ Ryan (2002) 211 CLR 540. In addition, during the course of this study I reviewed the High Court files for the matters which led to the decisions in Cattanach v Melchior (2003) 215 CLR 1 and D'Orta-Ekenaike v Victoria Legal Aid (2005) 223 CLR 1. Both these High Court files showed some evidence (for example in counsel's submissions and in Accompanying Material filed on behalf of the parties) that parties do make some references to SF (sourced and unsourced) during their written arguments to the High Court on appeal. 
submissions, expert witness testimony or the judge's own research. It is impossible to come to any conclusion about this from examining only the reasons for judgment using a content analysis method. ${ }^{107}$ However, it appears that most SF which were not sourced or referenced were drawn from judges' own general knowledge or intuition. They were ostensibly based on judicial conceptions of 'common sense' or 'common knowledge'. Despite statements from a number of judges in the cases studied of the dangers of judges using 'common sense' or 'common understanding' assumptions, ${ }^{108}$ judges explicitly used many terms which signalled judicial assumptions of common sense, 'common understandings', or common knowledge. These included:

It is notorious that... 109

Experience tells...110

Many citizens believe... ${ }^{111}$

But few would contend that...112

It may be readily accepted that... 113

It is common to speak of... 114

They are a well-known and natural phenomenon...115

107 An investigation of how judges implicitly use SF material is an area for further research This question would need to be investigated using different research methods, for example judicial interviews and surveys, or by using a different form of content analysis to investigate how SF in counsel's submission (oral and written) or expert evidence are reflected in judicial reasoning.

108 De Sales v Ingrilli (2002) 212 CLR 338, 405-6 [192] (Callinan J); Cattanach v Melchior (2003) 215 CLR 1, 64 [164] (Kirby J); Neindorfv Junkovic (2005) 222 ALR 631, 634 [9] (Gleeson CJ); Woods v Multi-Sport Holdings Pty Ltd (2002) 208 CLR 460, 511 [165] (Callinan J).

109 'It is notorious that over many years the first appellant and other members of the group of companies to which it belongs mined asbestos, and manufactured and supplied asbestosbased products. Very large numbers of their employees have been exposed to asbestos; many of them have contracted asbestosis and mesothelioma as a result...' CSR Ltd $v$ Eddy (2005) 226 CLR 1, 35 [80] (Gleeson CJ, Gummow and Heydon JJ).

110 'Experience tells that in human affairs there are many controvertible assertions, and, matters of science and mathematics apart, real disputation as to which facts may be and which may not be incontrovertible'. Fox v Percy (2003) 214 CLR 118, 168 [152] (Callinan J).

111 'Many citizens may believe that, in various matters, there should be more extensive government regulation. Others may be of a different view, for any one of a number of reasons, perhaps including cost.' Graham Barclay Oysters Pty Ltd v Ryan (2002) 211 CLR 540, 553 [6] (Gleeson CJ).

112 'But few would contend that travelling at 10 kilometres per hour was the only reasonable response to the risk of a motor car accident.' Graham Barclay Oysters Pty Ltd v Ryan (2002) 211 CLR 540, 586 [111] (McHugh J).

113 'It may readily be accepted that public authorities, armed with statutory powers to compel, prevent or punish conduct, frequently exercise informal and non-coercive influence or persuasion over those persons and organisations against whom they are empowered formally to act.' Graham Barclay Oysters Pty Ltd v Ryan (2002) 211 CLR 540, 610 [185] (Gummow and Hayne JJ).

114 'Another is that the market is mistaken on some basis other than manipulation. It is common to speak of shares being undervalued (or overvalued) by the market.' HTW Valuers (Central Qld) Pty Ltd v Astonland Pty Ltd (2004) 217 CLR 640, 658 [37] (Gleeson CJ, McHugh, Gummow, Kirby and Heydon JJ). 
A garage sale is a familiar event in Australian suburbia. (italics added) ${ }^{116}$

Examination will usually reveal that... 117

It is well understood that... 118

...explains the increasing awareness, both in the medical profession and in the community generally... 119

Observation confirms that, in this community, it is accepted... 120

....as is common knowledge...121

In the ordinary course... 122

Sometimes (perhaps often) the use of judicial intuition or judicial common sense as the basis for SF is uncontroversial and may contribute to efficient judicial reasoning. ${ }^{123}$ For example, 'a supply of pure water is a feature of Australian domestic life. Living in houses connected to a water supply is not unusual in Australia'124 is hardly likely to be contentious. However, there are also particular dangers that can arise from judicial use of 'common sense' or 'common knowledge', which impact on the accuracy of judicial

115 'Most of the time, the creek contained sand dunes known as bedforms. They are undulations on the floor of the creek, caused by the movement of water along the bed of the creek, particularly the movement of water caused by tides. They are a well-known and natural phenomenon, found in tidal estuaries around the world.' Mulligan $v$ Coffs Harbour City Council (2005) 223 CLR 486, 492-3 [12] (McHugh J).

116 Neindorf v Junkovic (2005) 222 ALR 631, 657 [100] (Callinan and Heydon JJ).

117 'Examination will usually reveal that the event came about as the result of a complex mixture of acts or omissions.' Pledge $v$ Roads and Traffic Authority (2004) 205 ALR 56, 59 [9] (Hayne J).

118 'It is well understood that the legal concept of causation differs from notions of causation which appear in the speculations of philosophers and the perceptions by scientists of the operation of natural laws.' Rosenberg v Percival (2001) 205 CLR 434, 460 [85] (Gummow J).

119 'A case such as that of Mrs Tame explains the increasing awareness, both in the medical profession and in the community generally, of the emotional fragility of some people, and the incidence of clinical depression resulting from emotional disturbance.' Tame $v$ New South Wales (2002) 211 CLR 317, 332 [14] (Gleeson CJ).

120 'Observation confirms that, in this community, it is accepted that there may be some circumstances in which reasonableness requires public authorities to warn of hazards associated with recreational activities on land controlled by those authorities. Most risky recreational activities, however, are not the subject of warning signs.' Vairy $v$ Wyong Shire Council (2005) 223 CLR 442, 427 [8] (Gleeson CJ and Kirby JJ).

121 'Not surprisingly, it was accepted, as is common knowledge, that the level of the ocean floor may and does change because of the movement of sand along the coast caused by currents and wind.' Vairy v Wyong Shire Council (2005) 223 CLR 442, 474 [187] (Callinan and Heydon JJ).

122 'In the ordinary course a person who is not injured will not have to husband a large sum of money over a long period of time in such a way as to ensure an even income stream but the complete exhaustion of the fund at the end of the period.' Willett $v$ Futcher (2005) 221 CLR 627, 643 [51] (Gleeson CJ, McHugh, Gummow, Hayne, Callinan and Heydon JJ).

123 Guthrie, Rachlinski and Wistrich have argued that 'eliminating all intuition from judicial decision-making is both impossible and undesirable because it is an essential part of how human brains function. Intuition is dangerous not because people rely on it but because they rely on it when it is inappropriate to do so.' See Chris Guthrie, Jeffrey Rachlinski and Andrew Wistrich, 'Blinking on the Bench: How Judges Decide Cases' (2007) 93 Cornell Law Review 1, 5.

124 Tepko Pty Ltd v Water Board (2001) 206 CLR 1, 54 [165] (Kirby and Callinan JJ). 
reasons and restrict the inclusion of the perspectives of marginalised groups ${ }^{125}$ and less dominant cultural worldviews ${ }^{126}$ in judicial reasoning. ${ }^{127}$ These dangers include judicial extrapolations of a judge's own personal unrepresentative 'private' knowledge as equivalent to the general knowledge of the community, failure to refer to or appreciate the life experiences of particular groups in the community (for example women, people with a disability, people of non Anglo-Saxon racial backgrounds, and lesbian, gay, bisexual and transgender people) and the use of SF which are inconsistent with available empirical research.

The content analysis study found that only $26 \%$ of judicial SF referred to a source or reference in some way. There were $351 \mathrm{SF}$ reference categories ${ }^{128}$ recorded for the 315 referenced or sourced SF. Some SF were referenced or sourced by judges to more than one kind of reference or source, resulting in a higher number of categories recorded than referenced SF. ${ }^{129}$ As demonstrated in Chart 5, the source for SF most frequently referred to by judges were cases (57\% of all category entries). The second most common source referred to was 'other source' (21.4\% of all category entries). Most references in this category were to legal sources such as legislation, expert evidence or general evidence, and counsel's submissions. There were also some references to law reform commission reports, other government reports and international instruments and covenants. The third most common category of source for SF was secondary

125 See discussion in Graycar, above n 25.

126 Cultural worldview refers to one's preferences about 'how society should be organised'. See discussion in Dan Kahan and Donald Braman, 'Cultural Cognition and Public Policy' (2006) 24 Yale Law and Policy Review 147. For recent discussion of empirical research into how cultural worldviews can impact on judicial reasoning see Dan Kahan, David Hoffman and Donald Braman, 'Whose Eyes Are You Going to Believe? Scott v. Harris and the Perils of Cognitive Illiberalism' (2009) 122 Harvard Law Review 837; Dan Kahan et al, "They Saw a Protest': Cognitive Illiberalism and the Speech-Conduct Distinction' (2012) 64 Stanford Law Review 851.

127 For further discussion of recent empirical research investigating the dangers that can arise from unconscious judicial use of intuitive reasoning, see Guthrie, Rachlinski and Wistrich, above n 123; Chris Guthrie, Jeffrey Rachlinski and Andrew Wistrich, 'Inside the Judicial Mind' (2001) 86 Cornell Law Review 777; Chris Guthrie, Jeffrey Rachlinski and Andrew Wistrich, 'The "Hidden Judiciary": An Empirical Examination of Executive Branch Justice (2008-2009) 58 Duke Law Journal 1477; Jeffrey Rachlinski et al, 'Does Unconscious Racial Bias Affect Trial Judges?' (2009) 84 Notre Dame Law Review 1195; Andrew Wistrich, Chris Guthrie and Jeffrey Rachlinski, 'Can Judges Ignore Inadmissible Information? The Difficulty of Deliberately Disregarding' (2004-2005) 153 University of Pennsylvania Law Review 1251.

128 Each SF record was reviewed and it was determined what kind of reference or source it referred to or contained. The case was coded for each 'category' of reference or source the SF referred to, rather than the total number of references or sources referred to by the SF. For example a SF which was referenced to four cases and one secondary source was coded once for the case category and once for the secondary source category.

129 A single SF might be referenced to both cases and a secondary source, which would have resulted in a case category and a secondary source category being recorded for that SF. For example in Cattanach v Melchior (2003) 215 CLR 1, 88 [240], Hayne J referred to the fact that 'sterilisation procedures have been available and used for much of the twentieth century'. This was sourced at $\mathrm{n} 454$ to a 1934 American case: Christensen $v$ Thomby (1934) 255 NW 620, and to a 1930 journal article: Miller and Dean, 'Liability of Physicians for Sterilisation Operations' (1930) 16 American Bar Association Journal 156. 
sources such as books and articles ${ }^{130}$ (17.66\% of all category records). The least common form of reference was empirical sources with only 14 SF (out of 1208 SF in total) citing an empirical source or reference (only $4 \%$ of all SF category entries, and $1.16 \%$ of all SF).

\section{Chart 5: Types of SF References}

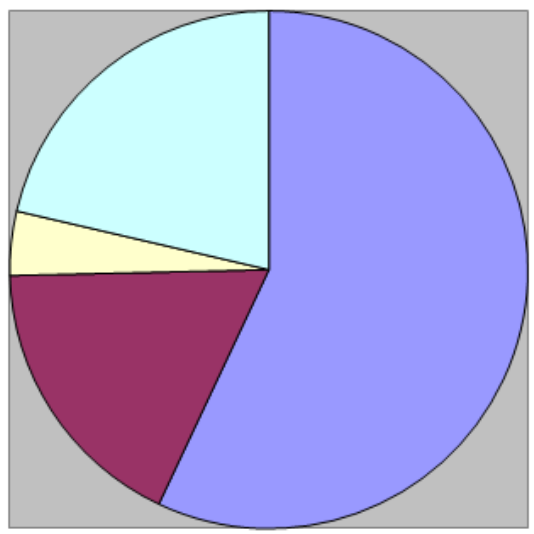

$$
\begin{aligned}
& \square \text { Case Ref } \\
& \square \text { Secondary Source } \\
& \square \text { Empirical Source } \\
& \square \text { Other Source }
\end{aligned}
$$

Traditional legal sources, such as reported cases, legislation and expert evidence, dominated the sources used by the judges for SF. However, 'legal' sources can be poor quality sources of SF information. The use of existing cases tends to simply reproduce judicial 'common sense' from one case to the next with the potential errors this brings. There is some evidence in the data from the content analysis that occasionally this problem might be circumvented when the cases referred to by a judge to support a SF themselves considered empirical or expert evidence related to the SF. This appears to have occurred in respect of a number of SF identified in the content analysis which concerned the reliability of assessments of witness credibility. ${ }^{131}$ However, this raises the further problem of potential judicial reliance on empirical findings (via an existing

130 These books and articles were predominantly legal books and articles. Books or articles which were published empirical studies were counted in the empirical evidence category.

131 Fox $v$ Percy (2003) 214 CLR 118, 129 [31] (Gleeson CJ, Gummow and Kirby JJ) referring to Samuels JA in Trawl Industries Pty Ltd v Effem Foods Pty Ltd (1992) 27 NSWLR 326, 328 (Samuel JA) ('Trawl') and noting also SRA (1999) 160 ALR 588,617-18. The SRA case was also referred to by Kirby J in Suvaal $v$ Cessnock City Council (2003) 200 ALR 1, 19 [73]; Rosenberg $v$ Percival (2001) 205 CLR 434, 488 [163]. He referred to the Trawl case in Suvaal v Cessnock City Council (2003) 200 ALR 1, 19 [71]. 
precedent) which are old and outdated. ${ }^{132}$ There was evidence that in a number of cases High Court judges drew on expert witness testimony or evidence given during the case as the basis for their SF statements. ${ }^{133}$ This judicial use of expert witness statements and testimony shows the potential of expert reports and testimony to introduce reliable SF information to the High Court. Despite some judicial reference to this kind of evidence in a number of cases it was not a widespread source for judicial $\mathrm{SF}$. In any event, there is research suggesting that even when material is introduced via expert witness there is no guarantee this will result in 'quality' SF. ${ }^{134}$

There were only fourteen instances where a judge provided some kind of direct empirical source for a SF. ${ }^{135}$ Examples of these included references by McHugh J to an

132 For example, the most recent empirical source noted in the material referred to in the Trawl and SRA cases (as cited in Fox v Percy (2003) 214 CLR 118) was 25 years old at the time of judgment in Fox $v$ Percy. The study of the impact of appearance and other personal characteristics on human credibility assessment has been described as giving rise to a 'huge' literature in the fields of social psychology and psychology and law. It is a sophisticated and constantly evolving body of literature, particularly in the last twenty years. See Barbara Spellman and Elizabeth Tenney, 'Credibility Testimony In and Out of Court' (2010) 17 Psychonomic Bulletin and Review 168; Stephen Porter, Leanne ten Brinke and Chantal Gustaw, 'Dangerous Decisions: The Impact of First Impressions of Trustworthiness on the Evaluation of Legal Evidence and Defendant Culpability' (2010) 16 Psychology, Crime and Law 477.

133 For example, in Cole $v$ South Tweed Heads Rugby League Football Club, Kirby J quoted from and accepted part of the expert report of a pharmacologist received into evidence detailing the effects of alcohol consumption: Cole v South Tweed Heads Rugby League Football Club (2004) 217 CLR 469, 498 [103]. A number of judges in Graham Barclay Oysters Pty Ltd $v$ Ryan referred to $\mathrm{SF}$ about the nature of the oyster growing process, and the process by which oysters can be subject to viral contamination: Graham Barclay Oysters Pty Ltd $v$ Ryan (2002) 211 CLR 540, 578-9 [88] (McHugh J), 588 [118] (Gummow and Hayne JJ), 615 [202] (Gummow and Hayne JJ). There were a number of SF identified in Swain $v$ Waverley Municipal Council, where judges referred to expert evidence about the hazards of swimming and the nature of beaches and beach formation: Swain $v$ Waverley Municipal Council (2005) 220 CLR 517, 523 [12] (Gleeson CJ), 523-4 [14] (Gleeson CJ), 549 [84] (McHugh J), 552 [95] (McHugh J), 552-3 [97] (McHugh J). In Woods v Multi-Sport Holdings Pty $L t d$, judges referred to expert evidence on issues such as the nature and history of indoor cricket as a sport, the frequency of eye injuries in sport including indoor cricket, and the wearing of helmets and protective equipment in sport generally: Woods v Multi-Sport Holdings Pty Ltd (2002) 208 CLR 460, 465-7 [4]-[11], 468-9 [22]-[24] (Gleeson CJ), 476-7 [57]-[59], 483 [77] (McHugh J), 486-8 [89]-[96] (Kirby J).

134 Note the concerns expressed by Gary Edmond in relation to the way in which Australian courts use expert evidence, which cast doubt on expert evidence being a panacea for poor quality SF. See Gary Edmond, 'Bacon's chickens? Re-thinking Law and Science (and Incriminating Expert Opinion Evidence) in Response to Empirical Evidence and Legal Principle' in Justin Gleeson and Ruth Higgins (eds), Constituting Law: Legal Argument and Social Values (2011) 93.

135 As noted in $\mathrm{n} 37$, this study considered the text of the High Court cases studied; it did not generally study the lower court decisions, or party oral or written submissions before the High Court. As part of general background research, written submissions and High Court files were only viewed in two cases: Cattanach $v$ Melchior (2003) 215 CLR 1 and D'OrtaEkenaike v Victoria Legal Aid (2005) 223 CLR 1. Accordingly, where it is not apparent in the High Court judgment how the judge sourced the empirical material no conclusion can 
Australian Institute of Health and Welfare report on costs of injury, ${ }^{136}$ and references by Kirby J to a report prepared by the National Centre for Social and Economic Modelling Pty Ltd for AMP setting out the costs of child-raising 137 and to the Kinsey reports (of 1948 and 1963) on human sexuality. ${ }^{138}$ Most of the empirical sources cited were research carried out by government bodies or the Australian Bureau of Statistics, with eight empirical references either to Australian Bureau of Statistics research ${ }^{139}$ or reports prepared by another government body. ${ }^{140}$ The empirical sources used by High Court judges identified in this study were also not necessarily comprehensive or necessarily up to date. The ease of availability of the empirical material to judges (for example, via counsel's submissions or as part of material filed by a party or judicial research), or existing familiarity with the empirical material seem to have been more likely influences on the judicial choice of empirical material than an assessment of whether the material was contemporary, comprehensive, valid and reliable.

generally be drawn on whether the research came from lower court decisions, from the parties' submissions or from the judge's own research.

Woods v Multi-Sport Holdings Pty Ltd (2002) 208 CLR 460, 477-8 [62] citing Colin Mathers and Ruth Penn, 'Health System Costs of Injury, Poisoning and Musculoskeletal Disorders in Australia 1993-4: Health and Welfare Expenditure Series Number 6' (Australian Institute of Health and Welfare, 1999) <http://www.aihw.gov.au/publication-detail/ ?id=6442467026>. See also the reference at 478 [62] to a survey carried out by the Australia Bureau of Statistics: Australian Bureau of Statistics, 'National Health Survey: Injuries, Australia' (1998), regarding the prevalence of injuries.

137 Cattanach v Melchior (2003) 215 CLR 1, 56 [144] citing Richard Percival and Ann Harding, 'AMP - NATSEM Income and Wealth Report Issue 3: All They Need is Love ... and Around $\$ 450000^{\prime}$ (National Centre for Social and Economic Modelling, 2002). <http:/ / www.natsem.canberra.edu.au/publications /?publication=ampnatsem-incomeand-wealth-report-issue-3-all-they-need-is-loveand-around-450000 $>$. The report on the costs of raising children was referred to in Appellants' Written Submissions to the High Court during the hearing of Cattanach $v$ Melchior and a copy was provided to the High Court as part of the accompanying materials filed for the Appellants. Appellants' Submissions and Accompanying Materials (Appellant) Volume 2, Submission in Cattanach $v$ Melchior, 24 January 2003. I noted these materials during a search of the High Court file for the Cattanach case carried out during the course of the research for this study.

Cattanach v Melchior (2003) 215 CLR 1, 44 [105] n 196, citing Alfred Kinsey, Wardell Pomeroy and Clyde Martin, Sexual Behaviour in the Human Male (1948) and Alfred Kinsey et al, Sexual Behavior in the Human Female (1953). The Kinsey Reports, although path breaking, are now 64 and 59 years old, respectively. They could not be said (of themselves) to represent 'current' empirical evidence from the field of human sexuality research. See, for example, some of the contemporary research carried out at the Kinsey Institute: The Kinsey Institute <http:/ / www.kinseyinstitute.org/>.

139 These included a number of references in De Sales $v$ Ingrilli (2002) 212 CLR 338 to Australian Bureau of Statistics data on marriage and divorce and to the growing incidence of de facto relationships. See for example the reference by Kirby J at 380 [117] n 100 to Australian Bureau of Statistics and Office of the Status of Women, 'Australian Women's Yearbook' (1997).

140 For example, the reference in Brodie v Singleton Shire Council (2001) 206 CLR 512, 538 [51] n 89 (Gaudron, McHugh and Gummow JJ) to Parliament of New South Wales Public Bodies Review Committee, 'Public Liability Issues Facing Local Councils' (November 2000). 


\section{DOES THE FREQUENCY AND SOURCE OF SF DIFFER BETWEEN JUDGES?}

There were commonalities in the way the individual High Court judges examined in this study referred to and sourced SF. For example, all judges referred to legal principles and adjudicative facts much more than SF in their judicial reasoning, all judges predominantly gave no sources for $\mathrm{SF}$, and where sources were given they were mostly to legal sources such as case law. But despite these commonalities the judges of the High Court are not a homogeneous group. In the same way that judges have different judicial philosophies, ${ }^{141}$ so different judges varied in how frequently they used and sourced SF in their judicial reasoning. Table 6 demonstrates that there were some variations in how frequently the judges studied utilised SF in their judgments. The frequency of use of SF in judgments ranged from the $9.27 \mathrm{SF} /$ judgment for Kirby J to $4.92 \mathrm{SF} /$ judgment for Gummow J and 4.8SF/judgment for Gaudron J. This suggests that there were differing propensities of individual judges in relation to the use of $\mathrm{SF}$ in judicial reasoning.

Table 6 Individual Judges and SF

\begin{tabular}{|c|c|c|c|c|c|c|}
\hline $\begin{array}{l}\stackrel{0}{0} \\
\stackrel{0}{0}\end{array}$ & 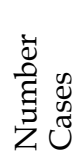 & 吾节 & 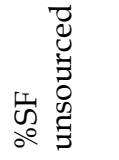 & 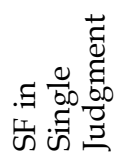 & 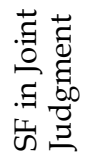 & 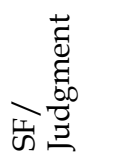 \\
\hline Kirby J & 37 & 343 & $67.35 \%$ & 245 & 98 & 9.27 \\
\hline Heydon J & 22 & 181 & $71.27 \%$ & $79^{142}$ & 102 & $8.23^{143}$ \\
\hline Gleeson CJ & 39 & 275 & $80.73 \%$ & 170 & 105 & 7.05 \\
\hline McHugh J & 39 & 268 & $71.65 \%$ & 208 & 60 & 6.87 \\
\hline Hayne J & 34 & 190 & $80 \%$ & 78 & 112 & 5.58 \\
\hline Callinan J & 42 & 225 & $78.67 \%$ & 160 & 65 & 5.36 \\
\hline Gummow J & 36 & 177 & $66.1 \%$ & 6 & 171 & 4.92 \\
\hline Gaudron J & 10 & 48 & $64.6 \%$ & 2 & 46 & 4.8 \\
\hline
\end{tabular}

It is unsurprising that Kirby J is the highest user of SF. He has a background somewhat different to other judges of the High Court. His background in law reform and other interests might suggest that he was more inclined to use SF in his judgments. It may also reflect his expressed philosophy of judicial honesty and openness in the use of policy matters in negligence judgments. ${ }^{144}$ It is perhaps surprising that Heydon J is the second highest user of SF/judgment, given his very critical views prior to appointment

141 For example, compare J D Heydon, 'Judicial Activism and the Death of the Rule of Law' (2003) 23 Australian Bar Review 1 and Michael Kirby, 'Judicial Activism? A Riposte to the Counter-Reformation' (2004) 24 Australian Bar Review 1.

142 All in Cattanach v Melchior (2003) 215 CLR 1.

143 If Cattanach $v$ Melchior was disregarded then Heydon's score for SF/judgment would have been only 4.8 .

144 Cattanach v Melchior (2003) 215 CLR 1, 52-3 [136], 59 [153]. At [153] Kirby J said 'if the application of ordinary legal principles is to be denied on the basis of public policy, it is essential that such policy be spelt out so as to be susceptible of analysis and criticism. Desirably it should be founded on empirical evidence, not mere judicial assertions'. 
to the High Court on the use of extra-legal reasoning in judicial decision-making. ${ }^{145}$ However, Heydon J is only the second highest user of SF/judgment because of the very high number of SF he used in one of his first judgments on the High Court in Cattanach $v$ Melchior. ${ }^{146}$ Cattanach accounts for all of the single judgment SF made by Heydon J. All other SF, used in 21 other cases, were made in joint judgments. If Cattanach was disregarded then Heydon J would have been one of the lowest users of $\mathrm{SF}$ on the High Court during the relevant period.

The other striking pattern that emerges from this data is that the highest judicial users of SF (apart from Heydon J), namely Kirby J, Gleeson J and McHugh J, have significantly more SF in single judgments than in joint judgments. The lowest judicial users of SF have significantly more SF in joint judgments. As will be discussed below, this may mean that overall judges appear more likely to make SF statements when they are alone in a single judgment, than when they are in a joint judgment with other judges. Gaudron J is the lowest SF user on a per judgment basis of the judges studied. ${ }^{147}$

Table 6 also demonstrates that there were differences between judges in relation to their use of references or sources for SF. Justices Gaudron, Gummow and Kirby were the most frequent users of a source for a SF. However, even those judges did not use sources for the majority of SF, with between $64.6 \%$ (Gaudron J) and $67.35 \%$ (Kirby J) of $\mathrm{SF}$ unsourced or unreferenced. There were also differences between judges in relation to the kind of sources they used for SF. Even the highest user of non-case law sources for SF, Gaudron J, McHugh J and Kirby J, only used secondary sources, empirical sources or other sources for just over $14 \%$ of SF. ${ }^{148}$ As discussed above, the use of case law as a source for SF tends to simply reproduce previous judicial use of 'common sense' recorded in precedent. It is perhaps unsurprising that two of the highest users of non-case law sources were McHugh J and Kirby J who have both showed an appreciation for the use of non-legal sources in judicial reasoning. ${ }^{149}$ These results are even more amplified when the 14 instances of empirically supported SF are considered. Four of these references were by Kirby J and seven were in the judgments of McHugh J. ${ }^{150}$ It is also perhaps unsurprising that the lowest users of sources other

145 Heydon, above n 141.

146 Cattanach v Melchior (2003) 215 CLR 1. See discussion in Burns, above n 22.

147 However, as Gaudron J only sat on ten of the 45 cases studied her results may not be directly comparable to the rest of the judges who sat on much higher numbers of cases. In addition, Gaudron J was not a member of the High Court in either of the two most prolific SF cases Cattanach v Melchior (2003) 215 CLR 1 and D'Orta-Ekenaike v Victoria Legal Aid (2005) 223 CLR 1.

148 Gaudron J used non-case law sources for $14.58 \%$ of referenced SF, McHugh J for $14.18 \%$ of referenced SF and Kirby J for $14.1 \%$ of referenced SF. The other judges used these sources even less - Gummow J 11.3\%, Gleeson CJ 9.09\%, Hayne J 7.37\%, Callinan J 5.78\% and Heydon J $4.97 \%$.

149 Cattanach v Melchior (2003) 215 CLR 1, 52-3 [136], 59 [153] (Kirby J); Woods v Multi-Sport Holdings Pty Ltd (2002) 208 CLR 460, 477-81 [62]-[70] (McHugh J).

150 This includes a SF in a joint judgment with Gaudron J and Gummow J in Brodie v Singleton Shire Council (2001) 206 CLR 512. 
than case law were Heydon J and Callinan J, who have both indicated some antipathy towards such sources of judicial reasoning. ${ }^{151}$

\section{SF AND GROUP EFFECTS: JOINT JUDGMENTS, SINGLE JUDGMENTS, MAJORITY JUDGMENTS AND DISSENTING JUDGMENTS}

Martinek has recently argued that group dynamics can impact on how judges use nonlegal factors in their decision-making, with membership in the small group of 'the court', with its shared cultural and legal norms, potentially driving more reliance on 'legal' factors than non-legal factors. ${ }^{152}$ This part shows that there were apparent 'group' effects in the results of the content analysis. Judges used SF more in single judgments than joint judgments, and more in dissenting judgments than majority judgments. When these factors were combined (for example single dissenting judgment) there were even greater effects on judicial use of SF.

There were differences in the frequency of the use of SF by judges dependent on whether they wrote a judgment as an individual or whether they wrote a judgment with other judges as part of a joint judgment. This difference can be seen below in Graph 7. The frequency of SF in single judge judgments (8.54 SF/judgment) was much higher than the frequency of SF in joint judgments (5.53 SF/judgment). Judges in joint judgments tended to use SF less (and presumably rely more on legal principles and adjudicative facts as a basis for judgment). These results appear to support the argument made by Martinek that grouping of judges tends to result in more reliance on legal rather than non-legal factors in judgments.

Care needs to be taken when considering the ramifications of the 'group' effect seen in these results for wider understanding of High Court judicial decision-making. Many of the single judgments in this study were by Justices Kirby, McHugh and Gleeson. As noted above, these judges were among the highest users of SF/judgment. What appears to be an effect related to the difference in judicial use of SF between single and group judgments could instead reflect wholly or partially individual characteristics of these particular judges. In addition, the results of this content analysis are confined to 45 negligence cases over a defined time period (2001-2005). There are possible differences that could be seen over other time periods, and as a result of different compositions and leadership of the High Court which might result in different group

151 See Heydon, above n 141; Woods v Multi-Sport Holdings Pty Ltd (2002) 208 CLR 460, 510-515 [162]-[169] (Callinan J). Callinan J concludes his judgment in the Woods case by 'referring to Disraeli's disdain for statistics by equating them with falsity'. One of the instances of SF referenced to an empirical source includes Callinan J's references to Australian Bureau of Statistics, 'National Health Survey: Injuries, Australia' (1998), however he cites the statistics to refute the arguments of McHugh J and finds the statistics 'unhelpful to the appellant's cause' (514 [169]). Writing extra-judicially Heydon J has, however, noted the widespread judicial use of SF, see above $\mathrm{n} 3$, and also referred to judicial use of empirical material in his recent judgment in Aytugrul v R (2012) 286 ALR 441, 462 [70]-[74].

152 Wendy Martinek, 'Judges as Members of Small Groups' in David Klein and Gregory Mitchell (eds), The Psychology of Judicial Decision Making (2010) 73, 77. See also Hon Harry Edwards and Michael Livermore, 'Pitfalls of Empirical Studies that Attempt to Understand the Factors Affecting Appellate Decisionmaking' (2008-2009) 58 Duke Law Journal 1895, 1964-6. 
dynamics and differences in court cohesion. ${ }^{153}$ However, the results certainly do raise interesting possibilities about how group dynamics affect judicial reasoning more generally. ${ }^{154}$

\section{Graph 7: Joint Judgments, Single Judgments and SF}

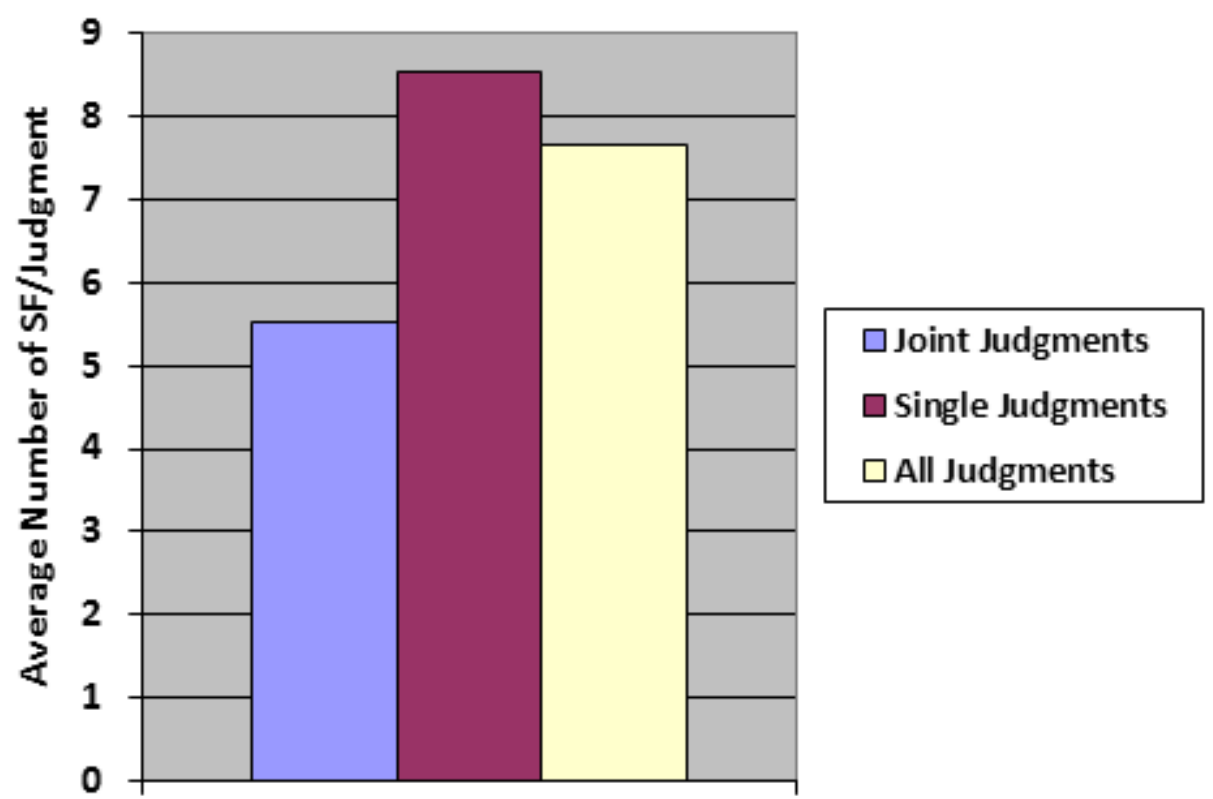

Type of Judgment

The other factor that had a significant effect on judicial use of SF identified in this study was whether a judge was part of the majority decision in a case, or was writing a dissenting judgment. Most SF occurred in majority judgments with 800 SF in 122 majority judgments. This is unsurprising because there are many more majority judgments (122) overall than dissenting judgments (36) in the cases studied. However, SF were far more frequent on a per judgment basis in dissenting judgments (11.33 $\mathrm{SF}$ /judgment) than in majority judgments (6.56 SF/judgment). Judges writing dissents used SF much more frequently than judges writing majority judgments.

Justice Kirby has argued that judicial dissent plays an important role in appellate judicial decision-making and encourages judicial honesty and transparency. ${ }^{155}$ It

153 For a discussion of the effects of court cohesion on judicial decision-making see Pierce, 'Institutional Cohesion in the High Court of Australia: Do American Theories Travel Well Down Under?', above n 44; Anika Gauja, 'High Court Review 2009: Exit Kirby, Enter Consensus?' (2010) 45 Australian Journal of Political Science 681.

154 Future research could investigate whether similar differences in judicial SF use could be seen between single and joint judgments in different categories of case, over different time periods and with different judicial composition and leadership of the High Court. 
appears from the results of this analysis that judges in dissenting judgments may indeed be more 'transparent' in their use of SF. Again, for similar reasons to those discussed above, care needs to be taken in extrapolating the effects of dissent shown in this study to the use of SF by the High Court generally. However, again the results show a fertile ground for research which compares the differences in the nature of judicial reasoning and judicial use of SF in majority and dissenting judgments. The factors of 'single' judgment and 'dissenting judgment' also appeared to have a combined effect. Most SF identified in the study were from single majority judgments (584 SF). However, the highest rate of SF/judgment occurred in single dissenting judgments (11.74 SF/judgment) and the lowest rate of $\mathrm{SF} /$ judgment in majority joint judgments (5.14 SF/judgment). As can be seen in Graph 8, even where a judgment was joint rather than single, the fact that it was dissenting still resulted in a large number of $\mathrm{SF} /$ judgment (8.8 SF/judgment). This is a much higher number of SF/judgment than in single majority judgments (7.3 SF/judgments).

\section{CONCLUSION}

It is clear that judges do use SF in their judicial reasoning in the High Court of Australia. The content analysis study discussed in this article confirmed that SF do form a part of the judicial reasoning 'tool box' in the High Court of Australia. SF play a range of roles in judicial reasoning including to set context and background, as social framework, and as part of policy statements. SF are not only used as part of consequence-based reasoning. Sometimes SF were referred to relatively infrequently in judicial reasoning, and much of the text of judicial reasoning is made up of the application of legal principles and rules to the adjudicative facts of the case. Of course, even where SF are used infrequently they may still exert considerable influence on a court's ultimate decision. The study also suggests, however, that in the most important and complex High Court cases SF are referred to frequently and can potentially play a very significant role in how judges craft their reasoning. The study also found that there were a number of factors that appeared to impact on how judges used SF in their reasoning, including how many judgments there were in a case, whether a judgment was a single or joint judgment, and whether a judgment was dissenting or majority. In addition, while there were significant commonalities in the way High Court judges used SF, there were also some differences, including frequency of use of SF and use of sources for SF. The study also found that judges most often did not source their SF. Where sources were used they were likely to be more traditional legal sources which were not always likely to be high quality sources of SF information. Judicial intuition and 'common sense' were the main sources of judicial SF statements, with the potential dangers this sometimes brings to judicial accuracy and legitimacy.

155 Justice Michael Kirby, 'Judicial Dissent: Common Law and Civil Law Traditions' (2007) 123 Law Quarterly Review 379; Justice Michael Kirby, 'Judicial Dissent' (2005) 12 James Cook University Law Review 4. On the value of dissent in the Australian High Court and societal dissent more generally see Andrew Lynch, 'Dissent: The Rewards and Risks of Judicial Disagreement in the High Court of Australia' (2003) 27 Melbourne University Law Review 724; Andrew Lynch, 'Taking Delight in Being Contrary, Worried About Being a Loner or Simply Indifferent: How Do Judges Really Feel About Dissent?' (2004) 32 Federal Law Review 311; Cass Sunstein, Why Societies Need Dissent (Harvard University Press, 2005). 
Graph 8: Dissenting, Majority, Single and Joint Judgments and SF

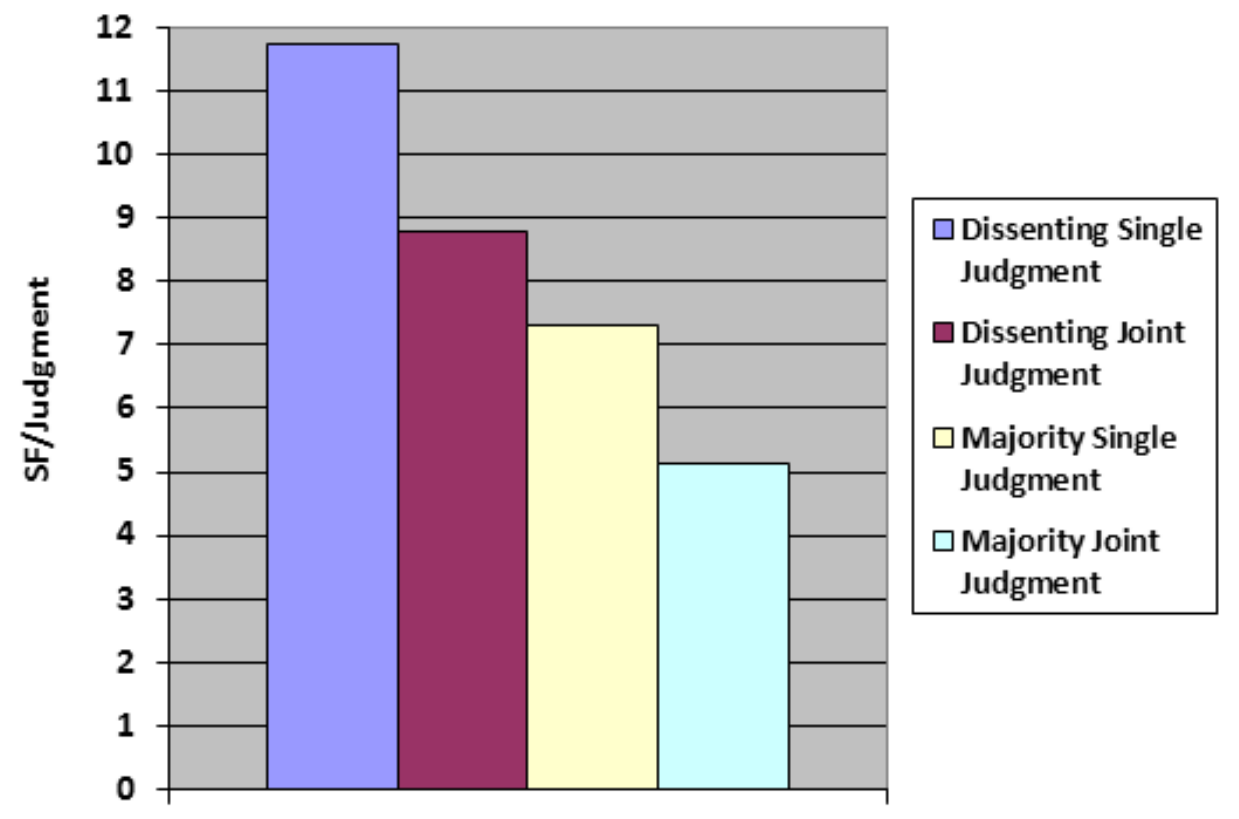

Type of Judgment

While judicial use of SF in the High Court has long been recognised, it has been a relatively unexplored and mysterious process. This study has contributed to our understanding of SF in judicial reasoning, but much mystery remains. Why do High Court judges use SF as they do? ${ }^{156}$ What is the relative importance of SF in judicial reasoning by comparison to adjudicative facts and legal principles? What does this mean for how we understand and theorise the judicial reasoning and judicial decisionmaking process? Will future studies of the High Court in different time periods, of different kinds of cases and during the tenure of different Chief Justices reveal similar or different patterns of judicial use of SF? Should the way High Court judges use SF be improved - for example should the High Court be encouraged and enabled to use more empirical material and better quality empirical material to support SF, rather than legal sources and judicial 'common sense'? ${ }^{157}$ These 'big' questions await another day.

156 I argue that this is a 'wicked' problem and there are likely multiple complex interrelated and interdependent legal, institutional, individual, cultural and cognitive processes that explain how judges use and construct SF. Wicked problems are 'complex, open-ended, and intractable.' 'Both the nature of the "problem" and the preferred "solution" are strongly contested.' See Brian Head, 'Wicked Problems in Public Policy' (2008) 3 Public Policy 101, 101.

157 Given the 'wicked' nature of the problem, any solutions are likely to be multiple, complex and interacting. Single factor reforms, such as improving information flow through devices 
Appendix 1: High Court Cases and Significance Code

\begin{tabular}{|c|c|c|c|}
\hline Year & Case Name & Citation & $\begin{array}{l}\text { Significance } \\
\text { Code }\end{array}$ \\
\hline 2001 & Rosenberg v Percival & (2001) 205 CLR 434 & $\mathrm{H}$ \\
\hline 2001 & Liftronic Pty Ltd v Unver & (2001) 179 ALR 321 & M \\
\hline 2001 & Derrick v Cheung & (2001) 181 ALR 301 & $\mathrm{~L}$ \\
\hline 2001 & Hollis v Vabu Pty Ltd & (2001) 207 CLR 21 & $\mathrm{H}$ \\
\hline 2001 & Brodie v Singleton Shire Council & (2001) 206 CLR 512 & $\mathrm{H}$ \\
\hline 2001 & Sullivan v Moody & (2001) 207 CLR 562 & $\mathrm{H}$ \\
\hline 2001 & Tepko Pty Ltd v Water Board & (2001) 206 CLR 1 & $\mathrm{H}$ \\
\hline 2002 & $\begin{array}{l}\text { Graham Barclay Oysters Pty Ltd v } \\
\text { Ryan }\end{array}$ & (2002) 211 CLR 540 & $\mathrm{H}$ \\
\hline 2002 & Frost v Warner & (2002) 209 CLR 509 & M \\
\hline 2002 & De Sales v Ingrilli & (2002) 212 CLR 338 & $\mathrm{H}$ \\
\hline 2002 & $\begin{array}{l}\text { Woods v Multi-Sport Holdings Pty } \\
\text { Ltd }\end{array}$ & (2002) 208 CLR 460 & $\mathrm{H}$ \\
\hline 2002 & $\begin{array}{l}\text { Tame v New South Wales; Annetts v } \\
\text { Australian Stations Pty Ltd }\end{array}$ & (2002) 211 CLR 317 & $\mathrm{H}$ \\
\hline 2003 & Joslyn v Berryman & (2003) 214 CLR 552 & $\mathrm{H}$ \\
\hline 2003 & New South Wales v Lepore & (2003) 212 CLR 511 & $\mathrm{H}$ \\
\hline 2003 & Cattanach v Melchior & (2003) 215 CLR 1 & $\mathrm{H}$ \\
\hline 2003 & Whisprun Pty Ltd v Dixon & (2003) 200 ALR 44 & M \\
\hline 2003 & Suvaal v Cessnock City Council & (2003) 200 ALR 1 & $\mathrm{~L}$ \\
\hline 2003 & Fox v Percy & (2003) 214 CLR 118 & M \\
\hline 2003 & Amaca Pty Ltd v NSW & (2003) 199 ALR 596 & $\mathrm{~L}$ \\
\hline 2003 & Hoyts Pty Ltd v Burns & (2003) 201 ALR 470 & M \\
\hline 2003 & Shorey v PT Ltd & (2003) 197 ALR 410 & $\mathrm{~L}$ \\
\hline 2003 & Dovuro Pty Ltd v Wilkins & (2003) 215 CLR 317 & M \\
\hline 2003 & $\begin{array}{l}\text { Gifford v Strang Patrick Stevedoring } \\
\text { Pty Ltd }\end{array}$ & (2003) 214 CLR 269 & M \\
\hline 2004 & $\begin{array}{l}\text { Woolcock Street Investments Pty Ltd } \\
v \text { CDG Pty Ltd }\end{array}$ & (2004) 216 CLR 515 & $\mathrm{H}$ \\
\hline 2004 & $\begin{array}{l}\text { Andar Transport Pty Ltd v Brambles } \\
\text { Ltd }\end{array}$ & (2004) 217 CLR 424 & M \\
\hline 2004 & Anikin v Sierra & (2004) 211 ALR 621 & $\mathrm{~L}$ \\
\hline 2004 & $\begin{array}{l}\text { HTW Valuers (Central QLD) Pty Ltd } \\
v \text { Astonland Pty Ltd }\end{array}$ & (2004) 217 CLR 640 & M \\
\hline 2004 & $\begin{array}{l}\text { Pledge } v \text { Roads and Traffic Authority; } \\
\text { Ryan } v \text { Pledge }\end{array}$ & (2004) 205 ALR 56 & M \\
\hline 2004 & $\begin{array}{l}\text { Colev South Tweed Heads Rugby } \\
\text { League Football Club }\end{array}$ & (2004) 217 CLR 469 & $\mathrm{H}$ \\
\hline 2005 & Vairy v Wyong Shire Council & (2005) 223 CLR 442 & $\mathrm{H}$ \\
\hline 2005 & Neindorf v Junkovic & (2005) 222 ALR 631 & M \\
\hline
\end{tabular}

such as amicus curiae or Brandeis briefs, are unlikely to be effective of themselves in improving the accuracy of judicial use of SF. 


\begin{tabular}{|c|c|c|c|}
\hline Year & Case Name & Citation & $\begin{array}{l}\text { Significance } \\
\text { Code }\end{array}$ \\
\hline 2005 & $\begin{array}{l}\text { Trustees of the Roman Catholic } \\
\text { Church for the Diocese of Canberra } \\
\text { and Goulburn v Hadba }\end{array}$ & (2005) 221 CLR 161 & M \\
\hline 2005 & Commissioner of Main Roads $v$ Jones & (2005) 215 ALR 418 & $\mathrm{~L}$ \\
\hline 2005 & Czatyrko v Edith Cowan University & (2005) 214 ALR 349 & M \\
\hline 2005 & $\begin{array}{l}\text { Mulligan v Coffs Harbour City } \\
\text { Council }\end{array}$ & (2005) 223 CLR 486 & M \\
\hline 2005 & Koehler v Cerebos (Australia) Ltd & (2005) 222 CLR 44 & M \\
\hline 2005 & Willett v Futcher & (2005) 221 CLR 627 & M \\
\hline 2005 & Laybutt v Glover Gibbs Pty Ltd & (2005) 221 ALR 310 & $\mathrm{~L}$ \\
\hline 2005 & $\begin{array}{l}\text { The Waterways Authority v } \\
\text { Fitzgibbon }\end{array}$ & (2005) 221 ALR 402 & M \\
\hline 2005 & Swain v Waverley Municipal Council & (2005) 220 CLR 517 & M \\
\hline 2005 & D'Orta-Ekenaike v Victoria Legal Aid & (2005) 223 CLR 1 & $\mathrm{H}$ \\
\hline 2005 & New South Wales v Bujdoso & (2005) 227 CLR 1 & M \\
\hline 2005 & $\begin{array}{l}\text { Thompson } v \text { Woolworths (QLD) Pty } \\
\text { Ltd }\end{array}$ & (2005) 221 CLR 234 & M \\
\hline 2005 & CSR Ltd $v E d d y$ & (2005) 226 CLR 1 & M \\
\hline 2005 & Manley v Alexander & (2005) 223 ALR 228 & $\mathrm{~L}$ \\
\hline
\end{tabular}




\section{Appendix 2: Individual Cases and SF}

\begin{tabular}{|c|c|c|c|c|}
\hline Case Name & No:SF & $\begin{array}{l}\text { No: } \\
\text { Para }\end{array}$ & $\begin{array}{c}\text { Judgments } \\
\text { (single + } \\
\text { joint) }\end{array}$ & Significance \\
\hline Cattanach v Melchior & 167 & 414 & 6 & $\mathrm{H}$ \\
\hline D'Orta-Ekenaike & 138 & 388 & 4 & $\mathrm{H}$ \\
\hline De Sales v Ingrilli & 75 & 198 & 5 & $\mathrm{H}$ \\
\hline Tame v NSW & 73 & 367 & 6 & $\mathrm{H}$ \\
\hline Woods v Multi-Sport & 71 & 170 & 5 & $\mathrm{H}$ \\
\hline Woolcock & 70 & 234 & 4 & $\mathrm{H}$ \\
\hline Brodie & 61 & 382 & 5 & $\mathrm{H}$ \\
\hline Lepore & 45 & 354 & 6 & $\mathrm{H}$ \\
\hline Cole & 43 & 133 & 5 & $\mathrm{H}$ \\
\hline Rosenberg v Percival & 41 & 224 & 5 & $\mathrm{H}$ \\
\hline Swain & 39 & 237 & 5 & M \\
\hline Graham Barclay Oysters & 37 & 332 & 6 & $\mathrm{H}$ \\
\hline Neindorfv Junkovic & 37 & 117 & 4 & M \\
\hline Vairy & 36 & 227 & 5 & $\mathrm{H}$ \\
\hline Fox v Percy & 33 & 155 & 3 & M \\
\hline Whisprun & 24 & 171 & 3 & M \\
\hline Dovuro & 22 & 177 & 6 & M \\
\hline Hollis v Vabu Pty Ltd & 22 & 124 & 3 & $\mathrm{H}$ \\
\hline CSR Ltd $v$ Eddy & 17 & 128 & 3 & M \\
\hline Gifford & 16 & 132 & 5 & M \\
\hline Fitzgibbon & 15 & 193 & 6 & $\mathrm{M}$ \\
\hline Suvaal & 13 & 151 & 3 & $\mathrm{~L}$ \\
\hline Tepko Pty Ltd & 12 & 172 & 4 & $\mathrm{H}$ \\
\hline Liftronic Pty Ltd & 11 & 102 & 4 & M \\
\hline Pledge & 10 & 51 & 4 & M \\
\hline Hadba & 10 & 51 & 2 & M \\
\hline Jones & 9 & 86 & 4 & $\mathrm{~L}$ \\
\hline Laybutt & 8 & 40 & 3 & $\mathrm{~L}$ \\
\hline Mulligan & 7 & 84 & 5 & M \\
\hline Koehler v Cerebos & 6 & 58 & 2 & M \\
\hline Hoyts Pty Ltd v Burns & 6 & 77 & 2 & $\mathrm{M}$ \\
\hline Joslyn v Berryman & 5 & 159 & 4 & $\mathrm{H}$ \\
\hline Thompson $v$ Woolworths & 5 & 43 & 1 & M \\
\hline Sullivan v Moody & 4 & 66 & 1 & $\mathrm{H}$ \\
\hline Andar Transport & 4 & 132 & 3 & M \\
\hline Frost v Warner & 3 & 86 & 3 & M \\
\hline Bujdoso & 3 & 52 & 1 & M \\
\hline Derrick v Cheung & 3 & 17 & 1 & L \\
\hline HTW Valuers & 2 & 70 & 1 & $\mathrm{M}$ \\
\hline Anikin v Sierra & 2 & 88 & 2 & $\mathrm{~L}$ \\
\hline Amaca Pty Ltd & 1 & 27 & 1 & $\mathrm{~L}$ \\
\hline Shorey v PT Ltd & 1 & 89 & 3 & $\mathrm{~L}$ \\
\hline Willett v Futcher & 1 & 56 & 1 & M \\
\hline Czatyrko & 0 & 18 & 1 & M \\
\hline Manley & 0 & 44 & 2 & $\mathrm{~L}$ \\
\hline
\end{tabular}

